\title{
San Pietro e Paolo d'Agrò, dalle origini al digitale
}

\author{
Giuseppe Di Gregorio
}

\section{Abstract}

L'immagine che il territorio esporta deriva da un processo di sedimentazione e stratificazione del paesaggio, proponendo scenari tipici e ricorrenti. Le prime descrizioni dei viaggiatori del '700 proposero i caratteri del paesaggio secondo uno spirito critico estraneo alla cultura locale, ma si rifecero alle emergenze storiche ricorrenti. Di contro episodi architettonici e paesaggistici particolari, talvolta atipici, rimasero allora come ora, poco conosciuti o descritti solo parzialmente. Risalendo il corso fluviale della valle d'Agrò in provincia di Messina, si scorge un paesaggio inusuale: una massiccia costruzione fortificata, caratterizzata da una torre svettante scandita da merlature con due torrette più basse. In questa parte della Sicilia le fortificazioni stanno sul mare o sulle alture circostanti. Avvicinandosi il paesaggio si trasforma, consegnando la percezione di una fabbrica religiosa. L'impianto chiesastico risale al periodo della riconquista normanna, voluto da re Ruggero, per la ricostruzione nel I I72 di una chiesa precedente dedicata ai santi Pietro e Paolo. La fabbrica sorge sul costone di levante, non visibile dal mare, ma in grado di presidiare la foce tramite una torre di fronte al monastero. L'intero paesaggio è una mediazione: tra la scena fluviale a valle e quella delle alture circostanti, tra l'architettura militare e quella religiosa, tra le fortificazioni poste sui crinali circostanti, tra l'architettura bizantina e quella normanna, tra un impianto longitudinale a croce latina e la tradizione centrica a croce greca. Nel presente lavoro si danno i primi risultati di un rilievo condotto con metodologia integrata laser scanner 3D e fotogrammetrica SFM, dell'analisi grafica, di VR.

Parole chiave

rilievo 3D, rilievo digitale, SFM, fotogrammetria, VR.

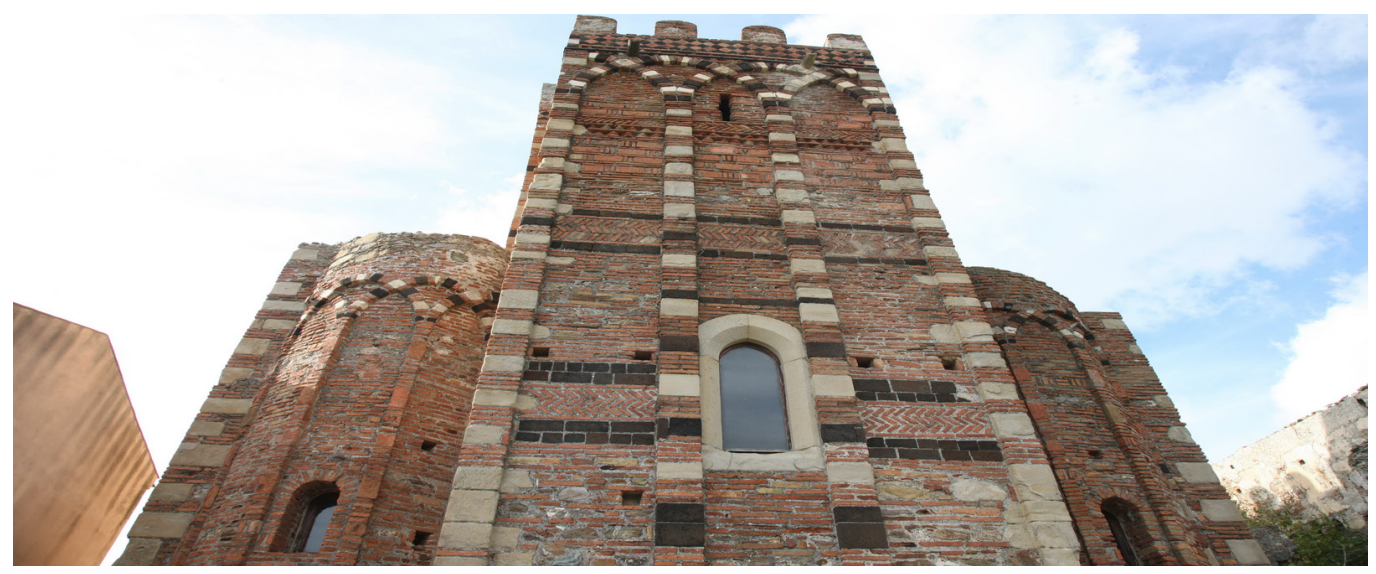




\section{Motivazioni e metodologia}

La ricerca ha per oggetto lo studio di una particolare chiesa basiliana dei Santi Pietro e Paolo d'Agrò, ubicata nel territorio di Casalvecchio Siculo in provincia di Messina, riconducibile al periodo della riconquista normanna. La scelta di studiare questo monumento è riconducibile a diverse ragioni:

- l'edificio di culto si colloca in un contesto più ampio, segnato da quel momento di passaggio tra la tradizione greca e quella latina, tra impianti centrali e impianti longitudinali, dove l'architettura diventa linguaggio simbolico dei rapporti reciproci tra uomo, clero, monarchia e divinità;

- la presenza di impianti basiliani dovuti a rifacimenti di quelli di rito greco, o a nuovi interventi, riconducibili al periodo della riconquista è un fenomeno diffuso nella val Demone: la chiesa di San Pietro e Paolo d'Agrò, rappresenta il momento evolutivo di questo fenomeno; - la possibilità di affrontare lo studio tramite rilievo digitale con laser scanner 3D e SFM, ha consentito una maggior precisione e approfondimento aggiungendo elaborazioni digitali in 3D, per trarre delle analisi puntuali;

- appartiene a quel tipo di monumenti che si potrebbero osservare per diverso tempo, e ogni volta trovare nuove particolarità.

Nel periodo dell'archimandritato di Messina del SS. Salvatore in lingua phari, una fervente attività edificatoria e di ricostruzione conta un numero superiore a settanta monasteri basiliani nella sola Val Demone, prevalentemente fortificati e collocati sui crinali di tortuose valli opportunamente nascosti al mare, interessando un territorio più vasto dell'attuale provincia di Messina [Basile 1975]. Così come quella di San Pietro e Paolo di Itala (ME), rappresenta per alcuni la prima fabbrica a partire dalla riconquista, quella della valle d'Agrò è considerata il più tardo e maturo risultato di una ricostruzione a partire di un precedente impianto. L'occasione di analisi di una delle chiese basiliane più studiate, più interessanti, ma anche più controverse del versante ionico dellisola e di tutta la val Demone, viene proposta con tecnologie avanzate di rilievo digitale, tra di loro integrate, e con un attenzione diVR.

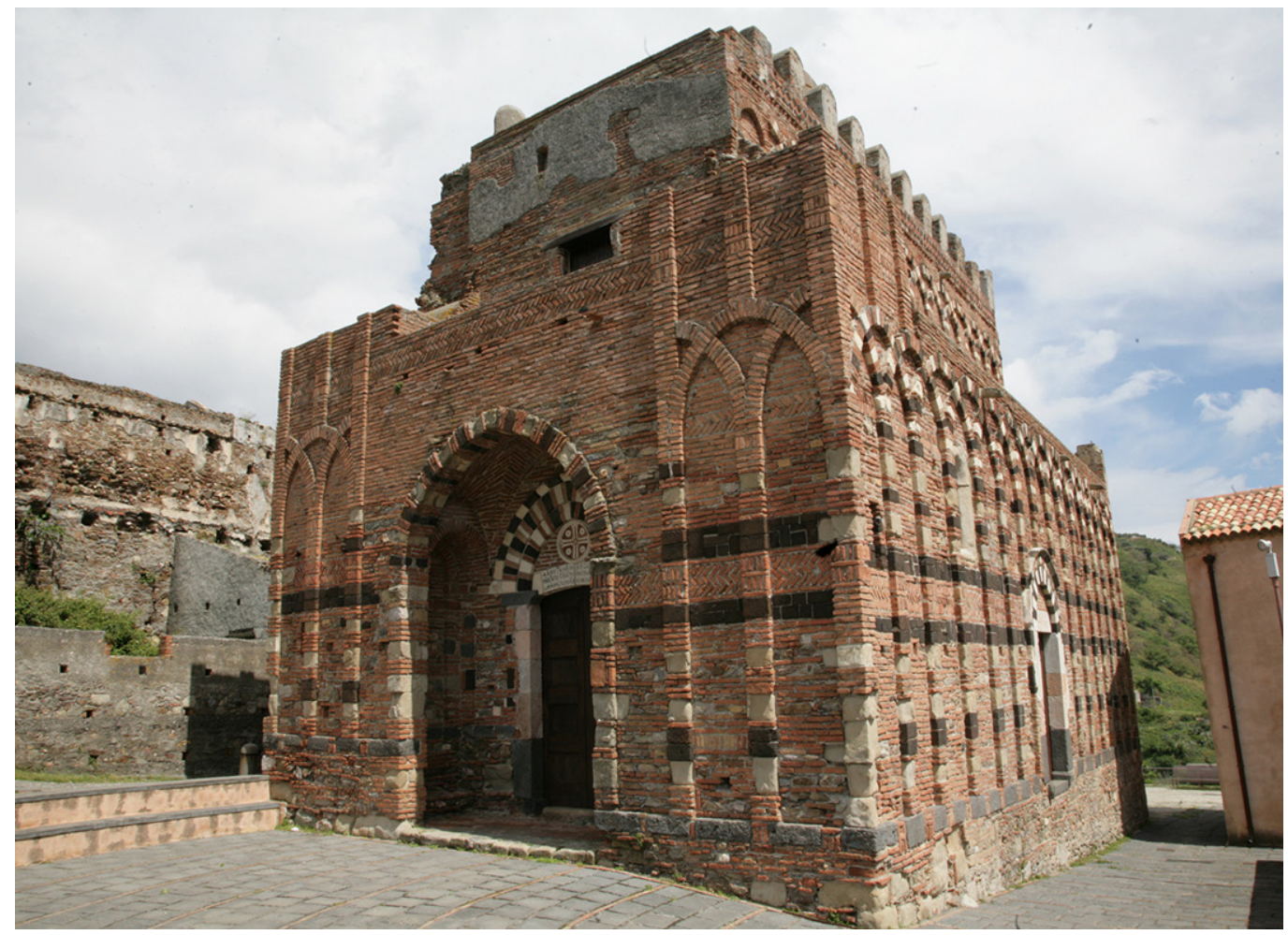




\section{Le notizie storiche}

Sappiamo che la chiesa primigenia risaliva presumibilmente all'incirca al 560, e che fu distrutta dagli arabi. Non è dato sapere cosa venne recuperato del primo impianto. La data di ricostruzione del I I 17, proviene da un 'Atto di Donazione' di Ruggero II, datato I I 6 redatto in lingua greca [I], da cui risulta che Ruggero II in viaggio da Messina a Palermo fa una sosta in scala S. Alexii, dove viene avvicinato dal monaco basiliano Gerasimo, il quale chiede al sovrano la facoltà e le risorse per riedificare (erigendi et readificandi) il monastero sito in fluvio Agrilea. Accolta la richiesta, il monaco Gerasimo, divenuto poi il primo abate di San Pietro e Paolo, si adoperò immediatamente a far erigere il tempio [Fazello 1817, pp. 137]. La ricostruzione di Gerasimo non è quella a noi pervenuta, il terremoto del I I69 produsse danni considerevoli e pur mantenendo lo stesso impianto, la chiesa odierna è riconducibile al I I72, come reca l'iscrizione in greco sul portale: "fu rinnovato questo tempio dei SS. Apostoli Pietro e Paolo da Teostericto Abate di Taormina, a sue spese. Possa Iddio ricordarlo. Nell'anno 6680. II protomagister Gherardo il Franco" [D'Amico 1979, p. 102] [2]. La precisazione che il capomastro fosse normanno conclude il processo architettonico, iniziato con lo stile bizantino e seguito da quello arabo. La particolarità più evidente della fabbrica sta nell'organizzazione architettonica, nella sintesi tra la centralità della croce greca e quella latina, tra l'alta e snella navata mediana prolungata sino alla torre absidale, e l'asse verticale della cupola. In alcuni studi è riportato che impianti a croce latina o commissa, con cupola monocentrica su una o più campate sono, in ambito bizantino da ricercare in Asia minore e in Armenia [Campo 1997, p. 97]. A conclusione dello scisma, del 1054, da cui risultava ormai formalizzata la dicotomia delle due concezioni religiose, la radice comune della fede sembra trovare la sintesi simbolica nell'organizzazione di questa fabbrica, in cui si equilibra e contrappone l'idea tra un impianto centrale, interprete di redenzione e di spiritualità contemplativa, e uno longitudinale simbolo di espiazione. Sintesi che non va ricercata nel significato storico o per opzione progettuale, ma solo per debito politico da parte dei monaci basiliani verso gli Altavilla, legati apostolici [3].

Senza soffermarsi sulla votazione ai Santi Pietro e Paolo a cui sono dedicate molte chiese della val Demone, va ricordato che la riconquista normanna per le sue necessità belliche, si appoggiò all'unica struttura ancora esistente sul territorio con la sua rete di informazioni: l'ordine monastico. Questo costituiva l'unica organizzazione strutturata in un territorio dove non esisteva più alcun controllo e assetto amministrativo dopo l'invasione musulmana.

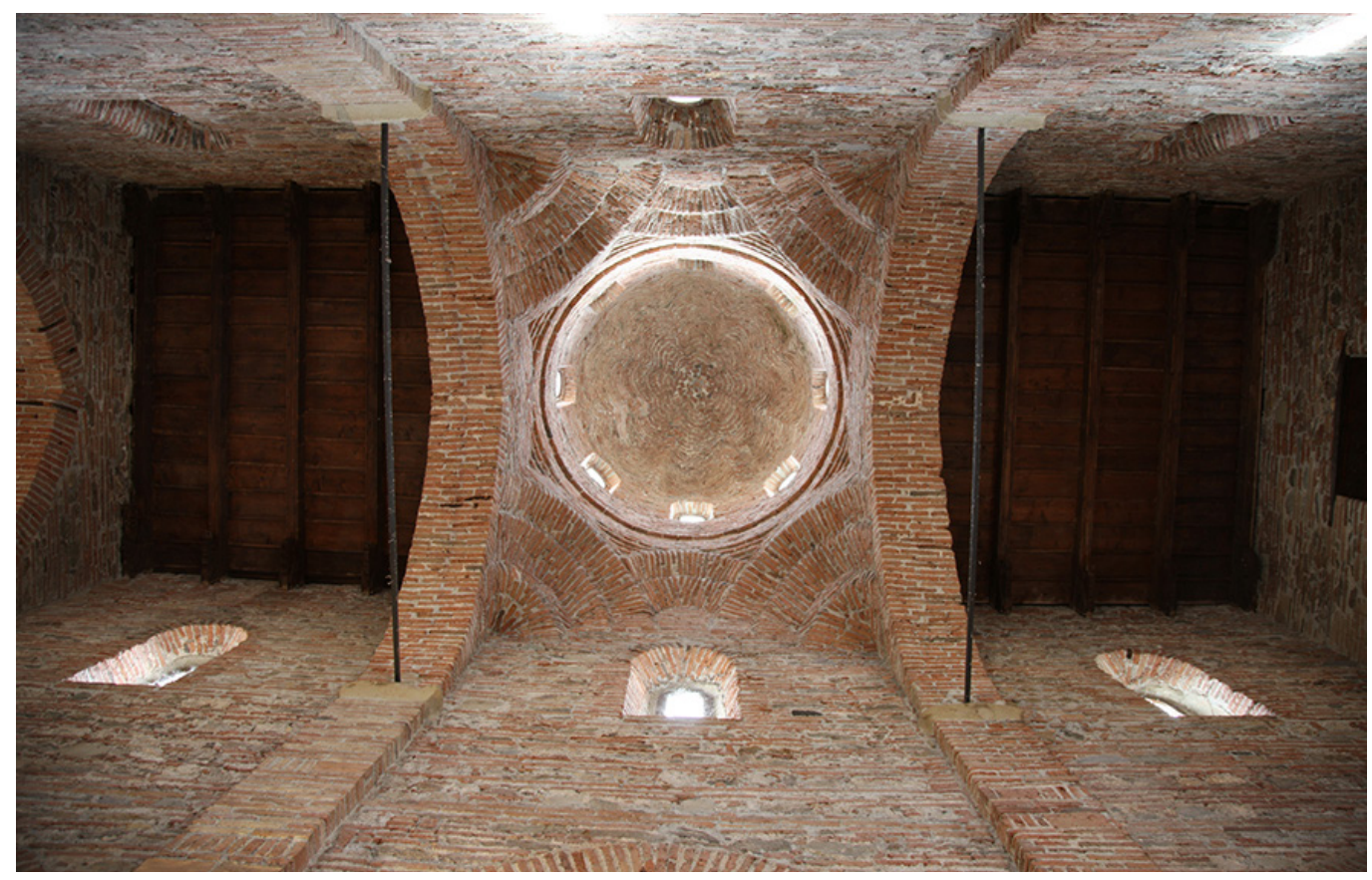


Non meraviglia quindi la richiesta dei monaci basiliani agli Altavila, nelle figure di Ruggero I e Ruggero II, per la riedificazione dei luoghi di culto della val Demone, essendo questa la prima parte dell'isola ad essere liberata. Né meraviglia che in un'area segnata in precedenza dalla tradizione greco ortodossa, con esempi di impianti a croce greca, adesso come tributo ai normanni si ritenne di edificare e ri-edificare impianti a croce latina. La croce e la spada, il cui segno si sovrappone e si confonde nell'immaginario simbolico, riconquistavano di pari passo il territorio.

\section{L'impianto architettonico}

La chiesa in pianta misura circa $20,54 \times 11,24 \mathrm{~m}$, dimensioni considerevoli riferite al periodo bizantino [4]. Tracciando una linea coincidente con la mezzeria della navata centrale si trova che forma un'angolo di 105 gradi con il nord, valore che non coincide con l'est, ma prolungando la linea, si trova che essa punta verso la città di Gerusalemme, un'operazione di orientamento interessante considerati i mezzi e le conoscenze dell'epoca. L'accesso alla chiesa è anticipato da un esonartece inserito tra due torri scalari, concluso allintradosso con una volta a crociera. Non è dato sapere se le due torri scalari, oggi assenti, appartenessero al primo impianto bizantino, del resto delimitavano la cappella imperiale, elemento che assume significato solo con l'avvento del regno normanno. All'interno le tre navate si concludono in altrettante absidi accusate all'esterno: le due laterali con la loro geometria curva e quella centrale falsata tramite un parallelepipedo. L'insieme di questi tre elementi si presenta impenetrabile, proprio da quel lato della fiumara che volge verso il mare ionico. La separazione delle navate è scandita da colonne sormontate da archi acuti, mentre nell'altra direzione quella longitudinale, lo spazio è ripartito in tre campate. Tale scelta si coniuga con l'idea di posizionare la cupola maggiore in posizione centrale, operazione non fattibile in altre situazioni con un ordine pari di campate, come ad esempio la vicina chiesa basiliana di San Pietro e Paolo di Itala, organizzata in quattro arcate. La navata centrale più elevata è caratterizzata dalle due cupole di cui quella di maggiori dimensioni conclude superiormente la campata centrale, l'altra quella minore anticipa l'abside centrale, mentre nelle rimanenti

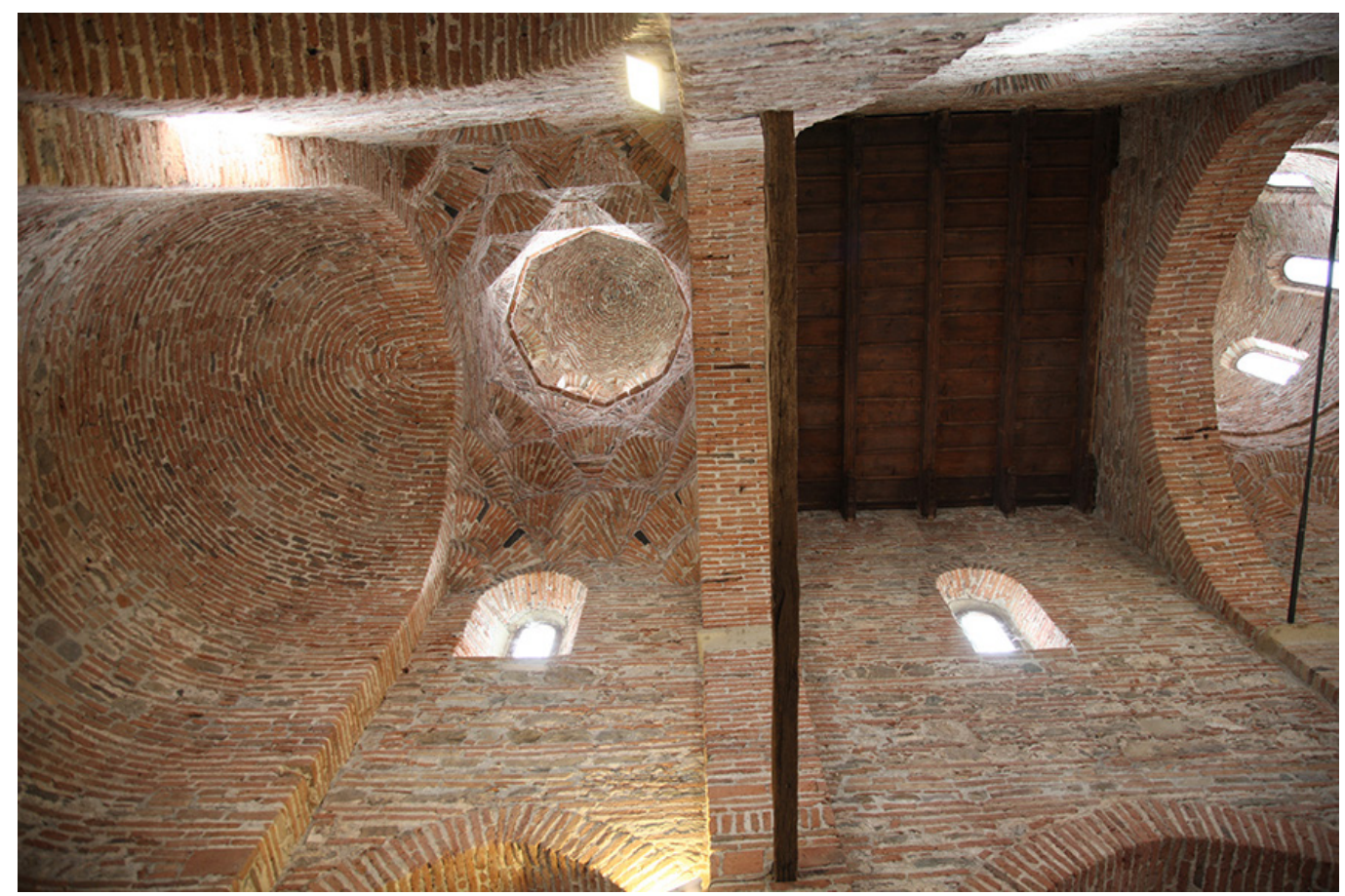




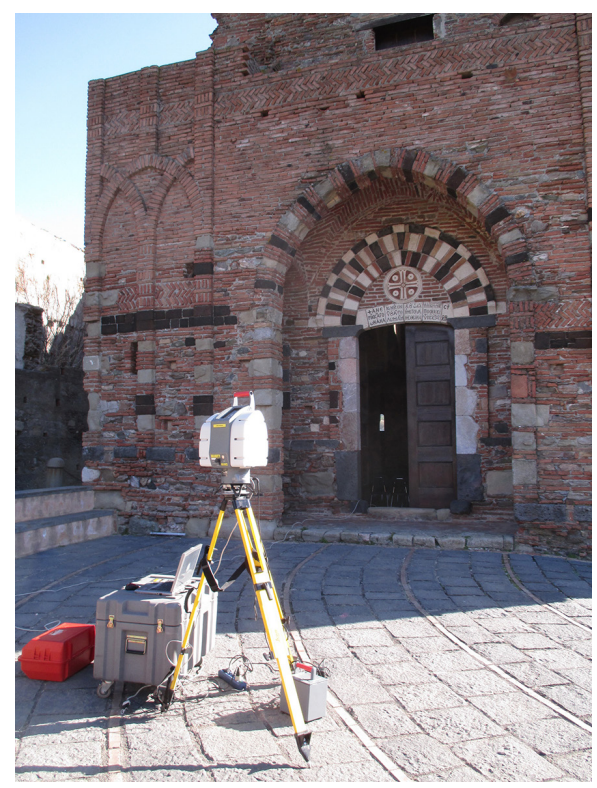

due campate la copertura è piana. Per trovare un altro impianto longitudinale a tre campate dello stesso periodo, normanno e basiliano, bisogna spostarsi in Calabria nella chiesa di Santa Maria de'Tridetti, dove però l'unica cupola risultava essere sul transetto. La centralità della cupola nei modelli religiosi occidentali non sembra trovare precedenti riscontri sulla mezzeria verticale dell'asse longitudinale. Tale particolarità è stata vista da più parti come la sintesi tra la centralità della croce greca e quella latina, tra l'alta e snella navata mediana prolungata sino alla torre absidale e l'asse verticale della cupola. Più strette e basse sono le navate laterali sormontate all'intradosso da crociere, impostate su pianta rettangolare. Ma la concessione agli Altavilla non si limita solo alla pianta a croce latina, il loro potere sancito con la legazia apostolica si manifesta in molte chiese dell'isola: la postazione del re è più elevata non solo di quella del clero, ma anche di quella dei sacerdoti, tale rappresentatività del ruolo è testimoniata dalla superstite finestra ancora visibile della cappella imperialis, oggi non più esistente. Costituita in origine da un corpo occidentale, posizionato al di sopra dell'esonartece, definito westwerk nella tradizione d'oltralpe, è sicuramente da attribuire al bagaglio di conoscenze del protomagister Girado il Franco, e del resto si coniuga con l'avvento della monarchia.

All'estradosso la copertura dell'intero impianto è piana ad eccezione delle due cupole, di cui quella centrale scarica il peso su quattro colonne che delimitano il rettangolo su cui è impostata la geometria sferica, il passaggio dal cerchio al rettangolo è mediato con sei ordini di pennacchi. Lungo il tamburo otto finestre consentono l'illuminazione e scandiscono gli otto spicchi della calotta. Le due porte laterali lungo le navate denunciano diverse difformità, la più evidente è il loro sfalsamento. Quella meridionale, posta in posizione mediana, è la più ambiziosa, ripetendo nell'arco parte dei motivi policromi del portale di ingresso, ma la sua significativa differenza di quota con il piano di campagna pone degli interrogativi sulla sua funzione. L'altra porta, quella lungo il lato settentrionale, collocata nell'ultima arcata, denuncia all'esterno sia lungo i piedritti che sopra l'architrave, un inserimento grossolano, lasciando inoltre visibile anche dall'interno la traccia di un precedente arco. All'esterno la pendenza del piano di campagna è livellata da uno zoccolo scandito da una listellatura e sfalsato in prossimità del nartece. Su tutti i lati esterni la decorazione avviene tramite delle lesene appena aggettanti che si concludono in sommità con una serie di archi intrecciati e che dividono il modulo della circonferenza a metà, lo stesso motivo è ripreso lungo i prospetti elevati della navata centrale. II materiale dominante e quindi il colore, è quello del laterizio, altri materiali si rifanno alle cave del luogo: la pomice lavica, l'arenaria gialla, il calcare. 
Fig. 5. La pianta e

sovrapposta la sezione

tale della nuvola

Fig. 6. Sezione verticale della nuvola, e restituzione grafica.
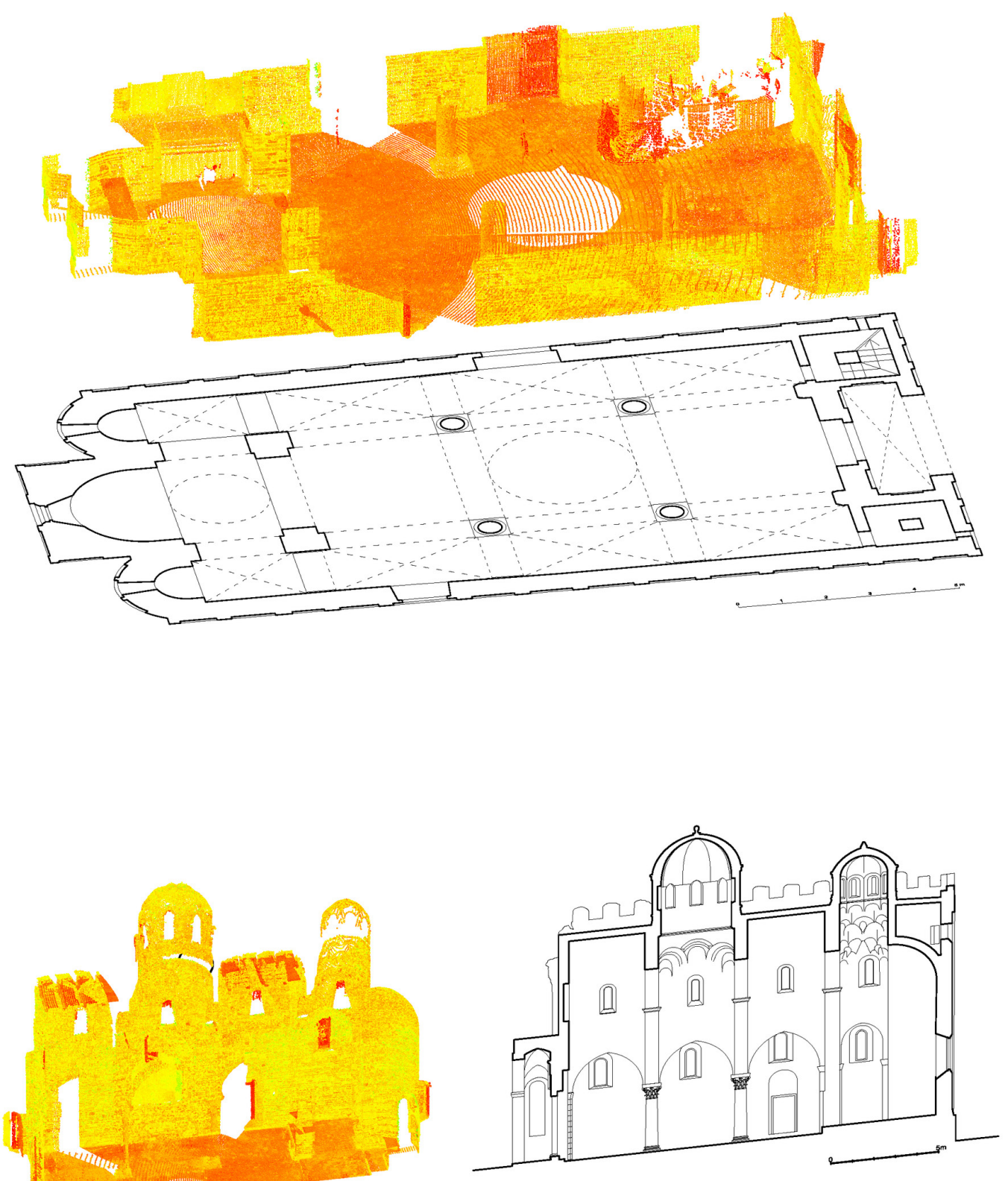


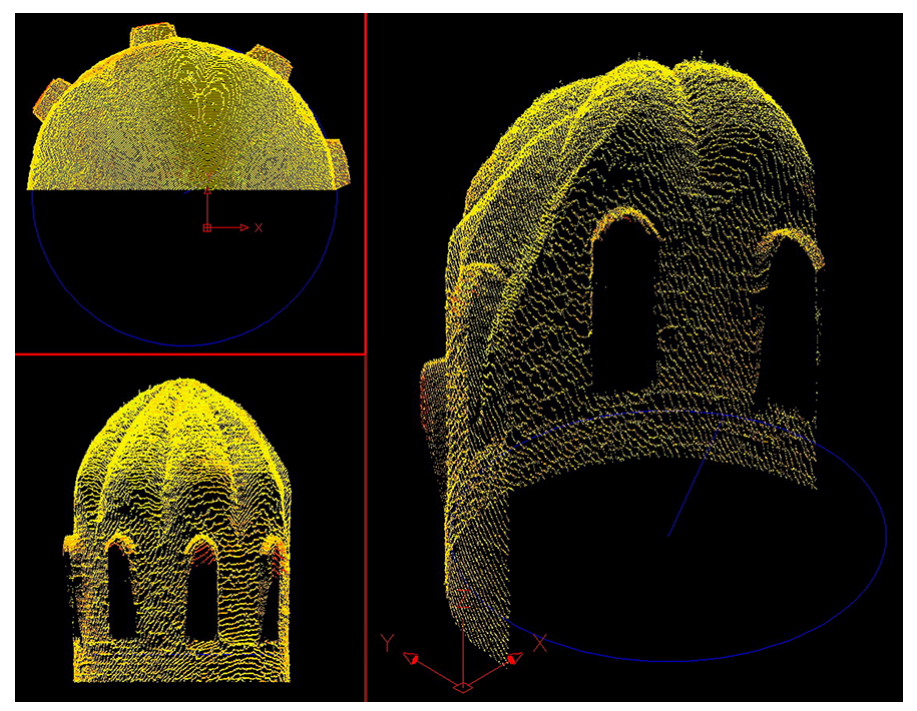

\section{II rilievo}

Lo studio è stato affrontato tramite laser scanner 3D, metodologia SFM e dense matching, alcune parti tramite rilievo diretto con distanziometro Leica Disto-D8 con sensore di inclinazione. II laser scanner 3D utilizzato è un Leica HDS 3000, a tempo di volo, con cui sono state eseguite due stazioni interne e tre esterne in modo da eliminare le zone d'ombra. Le due stazioni interne sono state eseguite con lo strumento in posizione zenitale al di sotto di ognuna delle cupole, in modo da riprendere l'intera geometria. La definizione dei punti è stata impostata con una griglia a maglia quadrata di I $\times 1 \mathrm{~cm}$ alla distanza media di 7,00 $\mathrm{m}$. Delle tre stazioni esterne la prima è stata collocata di fronte l'ingresso principale, la seconda in prossimità del cantonale di sud ovest, la terza a metà del lato occidentale allineata con la porta. La definizione delle nuvole esterne è stata impostata con una griglia di I × I $\mathrm{cm}$ alla distanza media di circa 8,00 m. Prioritariamente sono state unite le due scansioni interne, quindi separatamente le tre esterne. Inoltre le due scansioni esterne allineate in prossimità dei portali, hanno rilevato anche delle parti interne, in tal modo è stato possibile unire la totalità delle scansioni interne con quelle esterne. Per l'unione delle nuvole si è accettato un errore residuo massimo di $4 \mathrm{~mm}$, ottenendo così un unico modello numerico. Separatamente sono stati elaborati dei progetti SFM utilizzando i programmi Zephyr della 3DFlow, e Metashape della Agisoft, che hanno interessato: la globalità della parte esterna, il volume interno dell'esonartece, il prospetto relativo all'ingresso principale, l'esterno della parte absidata e l'interno della chiesa. Ė stata utilizzata una fotocamera Canon EOS-IDs Mark III full frame, il cui vantaggio è quello avere un angolo di campo maggiore negli spazi angusti. In fase di acquisizione fotografica è stata posta particolare attenzione alla nitidezza accettabile sull'intero fotogramma, coniugando diaframmi e tempi, tenendo anche conto che l'ottica utilizzata è stabilizzata. In fase di elaborazione è stato eseguito un controllo selettivo scartando quelle foto che mosse o sfocate perdevano di nitidezza anche solo in alcune parti. La difficoltà di questi programmi nell'eseguire l'unione in presenza di incertezze per i pixel causati da effetto scia è nota ed è stata trattata in diversi articoli. Quindi si è calcolato i) Ground Sampling Distance medio, per un campione di foto della parte esterna. Per le parti interne, tenendo conto dei parametri del sensore fotografico pari a $35,8 \times 23,9 \mathrm{~mm}$, il GSD è risultato pari a 2,4 mm/pixel, che per distanze medie dall'oggetto di circa $8 \mathrm{~m}$ significa un ricoprimento reale dell'immagine di 10,88 m di larghezza e 7,05 m di altezza. Questi valori sono stati ritenuti validi per le finalità del rilievo, poiché hanno assicurato una buona definizione del dettaglio compatibile con la qualità del rilievo eseguito con il laser scanner 3D. In fase di elaborazione SFM si è cercato un compromesso tra alcuni parametri significativi e i tempi di elaborazione, quali la densità dei Keypoint e la profondità fase di matching. Quindi si 
Fig. 8. La pianta: modulazione in pertiche greche e

canne siciliane e le matrici geometriche.

Fig. 9. Le sezioni: modulazioni e proporzioni delle parti in elevazione.
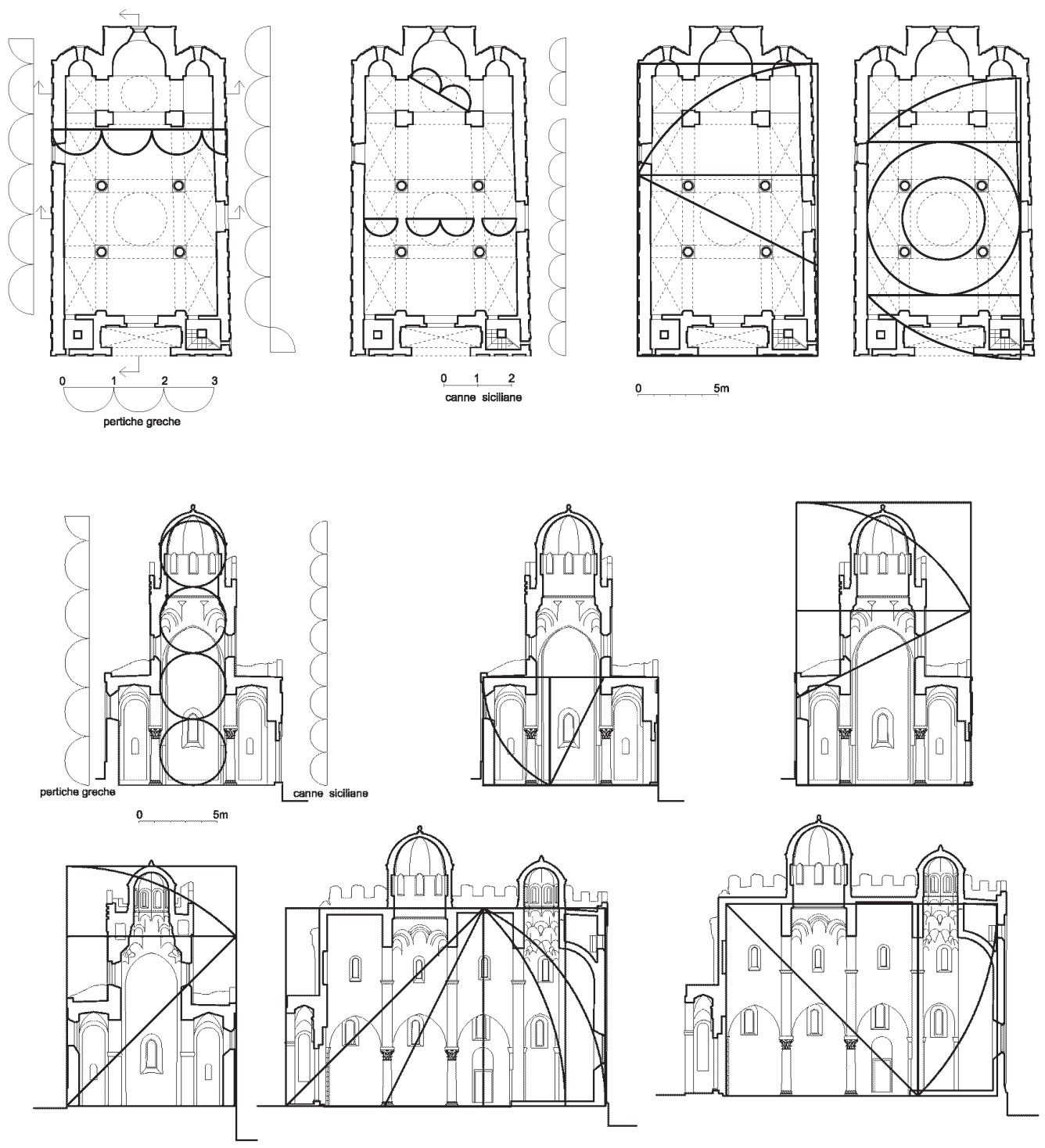

Fig. 10. Elaborazione modello SFM con Zephyr 3D Flow, vista 3D lati ovest e sud.

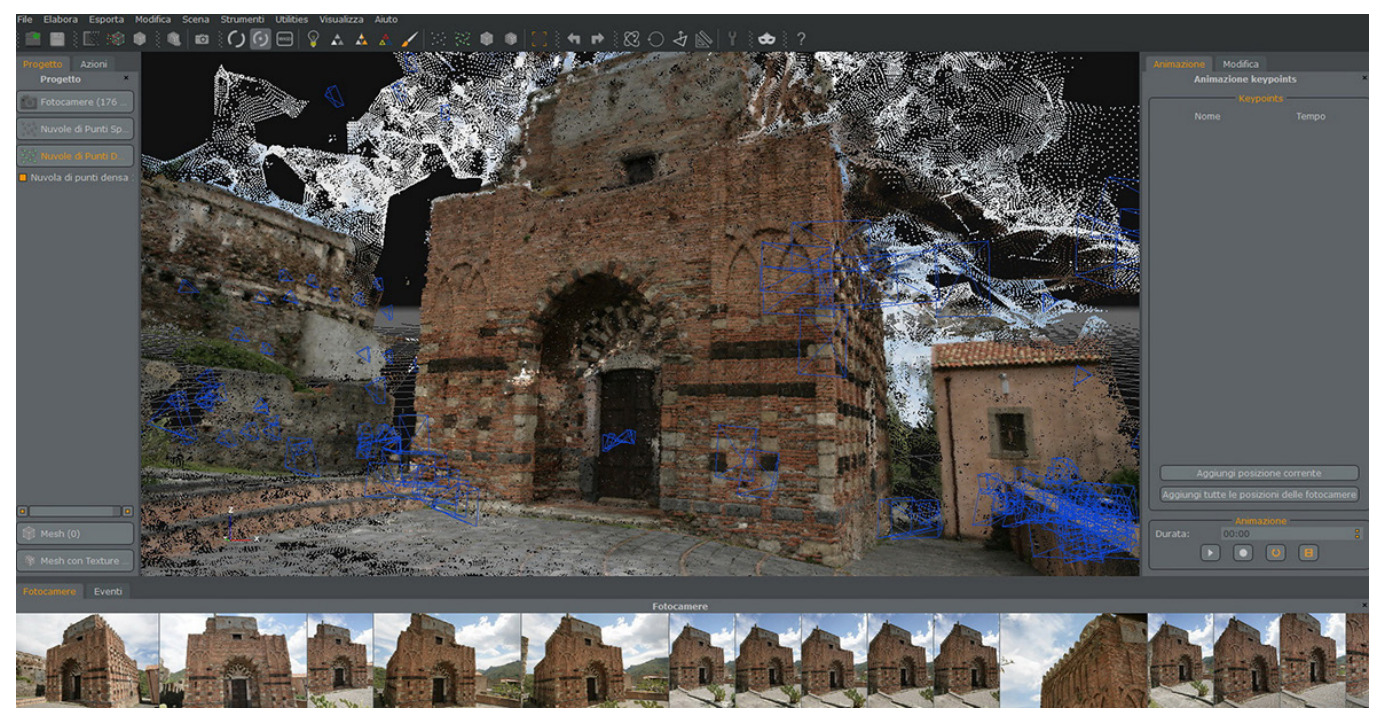


è elaborata la nuvola densa con mesh e texture, al fine di apprezzare la qualità in prossimità dei prospetti dei lati lunghi, ottenendo così il modello geometrico. Alcune criticità sono risultate in prossimità degli aggetti delle lesene. Successivamente è stato elaborato il modello numerico dei prospetti ovest e sud della nuvola laser, unendolo con i prospetti est e nord della nuvola SFM, ottenendo un unico modello numerico scalato. La fase di restituzione grafica della pianta è stata eseguita utilizzando la nuvola di punti a partire dall'applicativo Cloudworx. Misure di controllo sovrabbondanti sono state eseguite con il distanziometro laser Leica Disto-D8, per la verifica di alcune criticità come la convergenza dei lati lunghi nella direzione delle absidi.

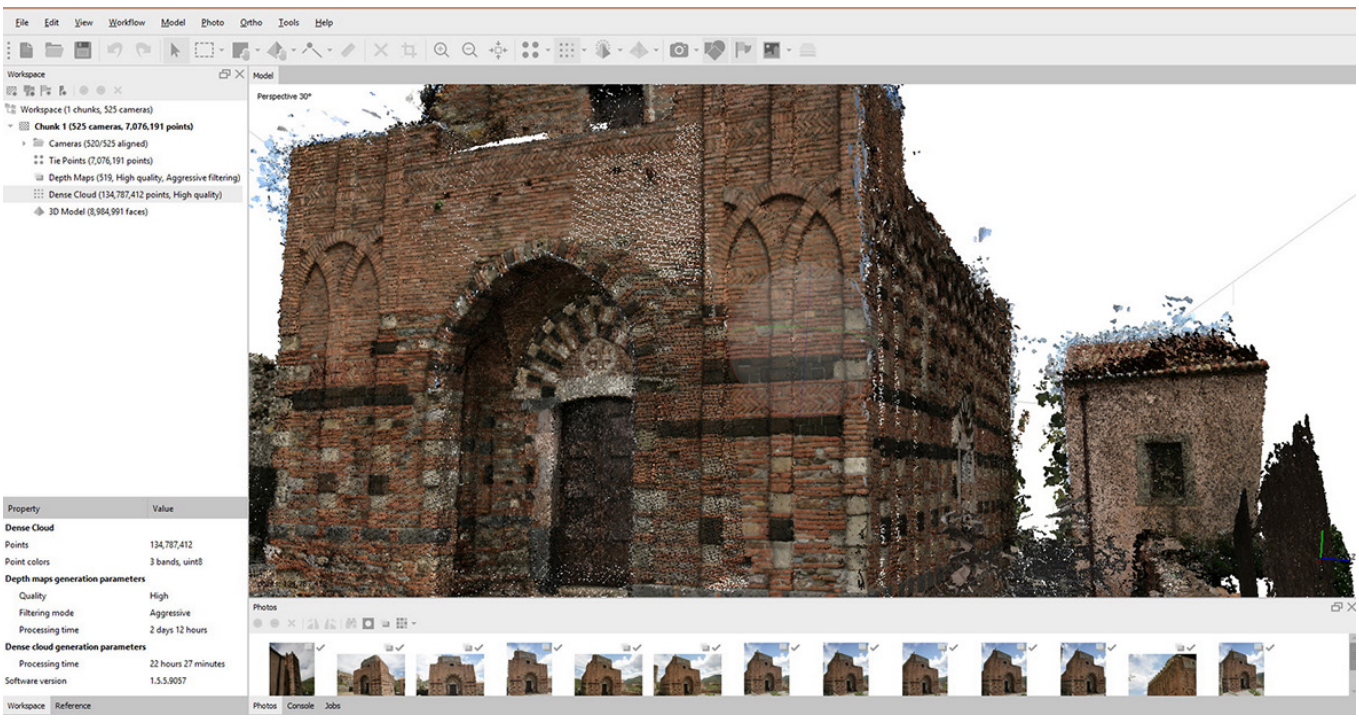

\section{I risultati ottenuti}

Come già detto non sappiamo quanto della chiesa a noi pervenuta appartenga all'impianto primigenio. Dei tratti più emblematici che testimoniano lo stile bizantino oggi ci rimane la ripartizione delle tre navate in tre moduli centrici, la policromia delle varie membrature, i capitelli, la croce greca al di sopra dell'architrave della porta d'ingresso. Di quello arabo, le due cupole con la parte terminale e la teoria di membrature a sostegno delle cupole. L'impronta normanna è evidente nell'ingresso scandito dalle torri, simbolo ricorrente nelle cattedrali normanne realizzate in Sicilia.

Dall'analisi grafica si sono ottenuti dei risultati che riguardano il dimensionamento e le proporzioni. È stata ricercata la modulazione della pianta e delle parti in elevazione a partire dalle sezioni. II modulo utilizzato è il piede greco [5] pari a m 0,3 I 2, il cui multiplo è la pertica pari a 10 piedi. Questa misura si ripete in pianta nelle due direzioni, che risultano essere 5,5 $\times 3$ pertiche per la parte interna, al netto delle murature e dell'esonartece, e 6,5 ×3,5 pertiche al massimo ingombro delle murature (figg. 8,9). In elevazione, in prossimità della cupola maggiore, sono state conteggiate 5,5 pertiche, con dei valori intermedi che scandiscono le parti significative. Le 5,5 pertiche pari a circa m 17,16 nelle due direzioni, sia in elevazione lungo la cupola maggiore che in direzione della navata centrale, dimostrano nel loro pareggiarsi il significato simbolico di mediazione tra le due tradizioni liturgiche. II valore di m 3, I 2 è pari al diametro della circonferenza misurata sul piano d'imposta della cupola maggiore e coincide con 10 piedi. Si potrebbe concludere che tutto l'impianto è stato dimensionato sulla circonferenza della cupola, organizzata sul modulo greco. Ė stata ricercata una modulazione anche con l'antica unità di misura delle canne siciliane [6], ma il risultato ottenuto soddisfa solo alcune parti. Riguardo alle matrici geometriche si è trovato che il rettangolo che definisce la 
pianta è definito dal rapporto aureo del quadrato avente lato pari alla larghezza dell'edificio. Quindi si è cercata anche un'altra proporzione a partire dal quadrato del nucleo centrale definito dalla circonferenza con centro nella proiezione della cupola e tangente ai lati interni della pianta, utilizzando il ribaltamento della diagonale (fig. 8). Anche in elevazione sono stati trovati dei rapporti tra le parti: l'altezza della cupola maggiore è definita da un rapporto aureo con la larghezza dell'edificio, la cupola minore è definita dal ribaltamento della diagonale del quadrato di lato pari alla larghezza dell'edificio. Rapporti basati sulla proporzione aurea e sul ribaltamento della diagonale sono stati trovati nella sezione longitudinale della navata centrale (fig. 9).

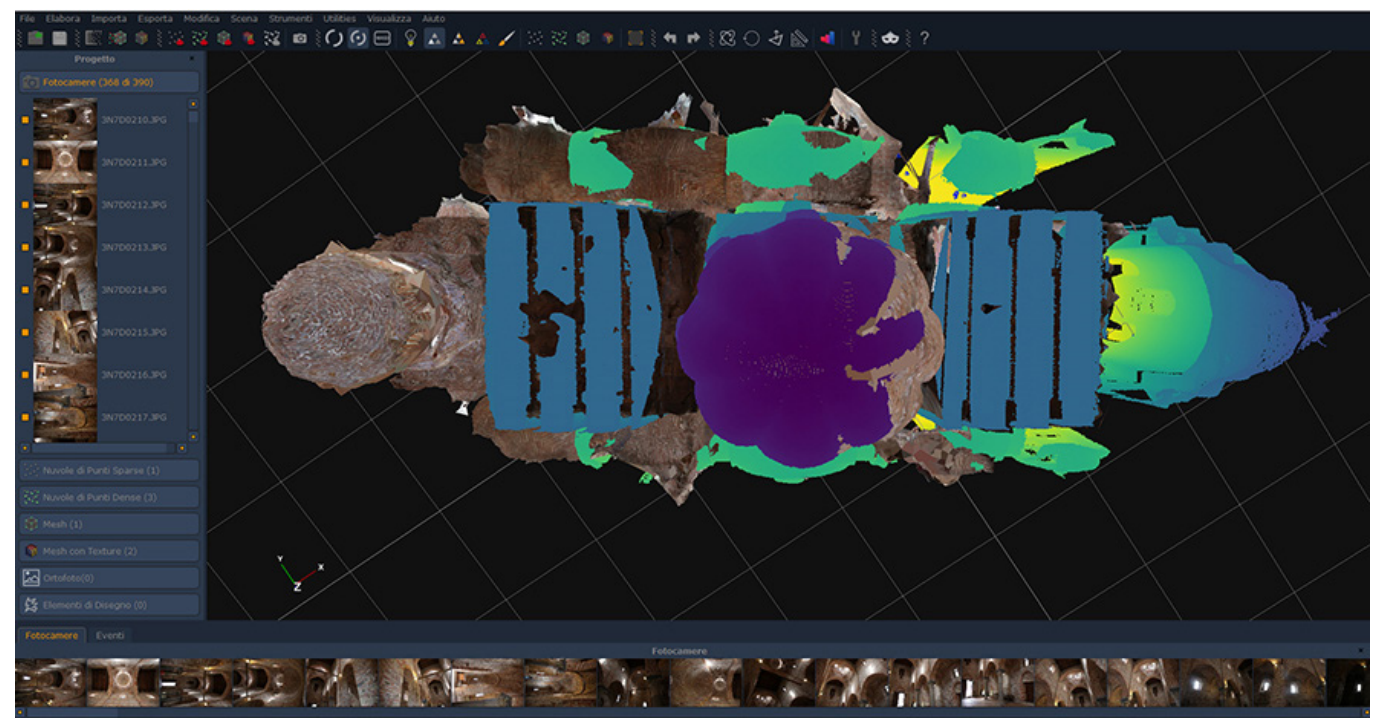

\section{Conclusioni}

Modulazioni, proporzioni, segni, disegni, interpretazioni della croce in quel richiamo a quel vedere latino e greco, indispensabile per ritrovare la chiave di lettura di quegli esempi invariabili di tutte le cose che sono state. In questo tempio di culto traspare l'apicale luogo di dialoghi e relazioni tra civiltà e culture differenti, nella eterna ricerca del superamento dei conflitti e delle divisioni. Un edificio di culto sulla foce di un fiume che arriva ad un mare 'stretto' tra due terre, ma ancora più stretto da sempre tra tante civiltà.

\section{Note}

[I] Conservato nel Codice Vaticano 820I, tradotto in latino da Costantino Lascaris nel I478.

[2] L'anno 6680 corrisponde nella cronologia greco- bizantina al I 172. L'iscrizione sul portale è in greco la traduzione presente su diversi volumi è stata presa da: D’Amico Mario (1979). Palachorion. Catania-Verona: Niccolò Giannotta Editore, p. 102.

[3] Al re era attribuito il potere dell'investitura dei sacerdoti e di giudice sulle questioni religiose [Campo 1997, p. 96]

[4] Per le dimensioni degli edifici di culto nella Sicilia bizantina si veda: Buscemi, Tomasello 2008, pp | 3 I, I 32.

[5] Anche se si discosta di poco da quello romano pari a 0,2956 m. È interessante l'osservazione a dimostrazione di come la fabbrica e il territorio fossero permeati dalla cultura bizantina anziché dalla tradizione romana. La misura pari al piede greco oscilla tra m 0,308 e m 0,3 I 5 [Buscemi, Tomasello 2008, pp. I I0- I I I].

[6] Nel periodo normanno veniva utilizzata la canna composta da 8 palmi avente valore di 2, I 09360 metri, che sarà legalizzata con dei correttivi dall'editto del 6 aprile 1480, emanato da Ferdinando I d'Aragona. 


\section{Riferimenti bibliografici}

Arena Marinella, Colistra Daniele, Mediati Domenico (2019). Architettura bizantina in Tessaglia. Le chiese del Monte Kissavos In Stefano Bertoccci, Antonio Conte (a cura di). II Simposio UID di internazionalizzazione della ricerca. Patrimoni culturali, Architettura, Paesaggio e Design tra ricerca e sperimentazione didattica. Atti del Symposium of Representation Scientific Area for the development of multidisciplinary International programs. Matera, 22 ottobre 2019 . Firenze: diapress, pp. 74-79.

Basile Francesco (1938). Chiese siciliane del periodo normanno, I monumenti italiani, fasc. XV. Roma: Accademia d'Italia.

Basile Francesco (1975). L'architettura Della Sicilia Normanna. Catania-Caltanissetta:Vito Cavallotto Editore.

Bottari Stefano (1927). Nota sul Tempio normanno dei SS. Pietro e Paolo d'Agrò. Messina:Tipografia ditta D'Amico.

Bottari Stefano (1939). Chiese basiliane della Sicilia e della Calabria. Messina: Officine grafiche Principato.

Buscemi Francesca, Tomasello Francesco (2008). II paesaggio Tardoantico del territorio. In Buscemi Francesca, Tomasello Francesco (a cura di). Una testimonianza di cristianizzazione orientata. Palermo: Alberto Musco, pp. I31, I32. <www. progettokasa.net>.

Calandra Enrico (1938). Breve storia dell'architettura in Sicilia. BaRi: Laterza. Ristampa (1996) Torino:Testo \& Immagine.

Campo G. (1997). Casalvecchio Siculo, Monastero dei SS. Pietro e Paolo d'Agrò. In I Quaderni dell'Abbazia, 2, 1997.

D’Amico Mario (1979). Palachorion. Verona: Edizioni Giannotta.

Fazello Tommaso (1817). Della Storia di Sicilia - Deche Due. Vol. I. Palermo: Tipografia Giuseppe Assenzio. (Traduzione in lingua toscana). Archiviato il 29 novembre 2015 in Internet Archive: <https://archive.org/details/bub_gb_hM2XPuLTSDgC/ mode/2up>.

Freshfield Edwin Hanson (1918). Cellae trichorae and other christian antiquities in the byzantine provinces of Sicily with Calabria and North Africa including Sardinia, vol.2, p. 894. London: Rigon \& Arnold. Ristampa (20 I0) Londra: La Vergne: General.

Mamì Antonella (2008). Le chiese basiliane della Sicilia orientale. In Costruire in laterizio, $n^{\circ}$ I23, maggio-giugno.

Noto Vittorio (20 I2). Architetture medievali normanne e siculo normanne. Palermo: Pietro Vittorietti Edizioni.

Pirro Rocco (1733). Sicilia Sacra. 2 voll. Palermo: edizione Panormi. (Ristampa anastatica, Editore Forni, collana Italia sacra, dicembre 1987)

\section{Autore}

Giuseppe Di Gregorio, Università degli Studi di Catania, giuseppe.digregorio@unict.it

Per citare questo capitolo: Di Gregorio Giuseppe (2020). San Pietro e Paolo d'Agrò, dalle origini al digitale/San Pietro e Paolo d'Agrò, from origins to digital. In Arena A., Arena M., Brandolino R.G., Colistra D., Ginex G., Mediati D., Nucifora S., Raffa P. (a cura di). Connettere. Un disegno per annodare e tessere. Atti del $42^{\circ}$ Convegno Internazionale dei Docenti delle Discipline della Rappresentazione/Connecting. Drawing for weaving relationships. Proceedings of the 42th International Conference of Representation Disciplines Teachers. Milano: FrancoAngeli, pp. $3247-3268$. 


\title{
San Pietro e Paolo d'Agrò, from Origins to Digital
}

\author{
Giuseppe Di Gregorio
}

\section{Abstract}

The image that the territory exports derives from a process of sedimentation and stratification of the landscape, offering typical and recurring scenarios. The first descriptions of the travelers of the '700 proposed the characteristics of the landscape according to a critical spirit extraneous to the local culture, but they referred to the recurring historical emergencies. On the other hand, particular architectural and landscape episodes, sometimes atypical, remained then as now, little known or only partially described. Going up the river course of the D'Agrò valley in the province of Messina, you can see an unusual landscape: a massive fortified building, characterized by a towering tower punctuated by battlements with two lower turrets. In this part of Sicily the fortifications are on the sea or on the surrounding hills. Approaching, the landscape is transformed, delivering the perception of a religious factory. The church structure dates back to the Norman reconquest, commissioned by King Ruggero, for the reconstruction in 1172 of an ancient church dedicated to Saints Peter and Paul. The church stands on the eastern ridge, not visible from the sea, but capable of guarding the mouth of the river, through a tower in front of the monastery. The whole landscape is a mediation: between the river landscape downstream and that of the surrounding hills, between military and religious architecture, between the fortifications placed on the surrounding ridges, between the Byzantine and Norman architecture, between a longitudinal Latin cross layout and the centric Greek cross tradition. In this work, the first results of a survey conducted with an integrated 3D laser scanner method and SFM photogrammetry are given, graphic analysis, VR.

Keywords

3D survey, digital survey, SFM, photogrammetry, VR.

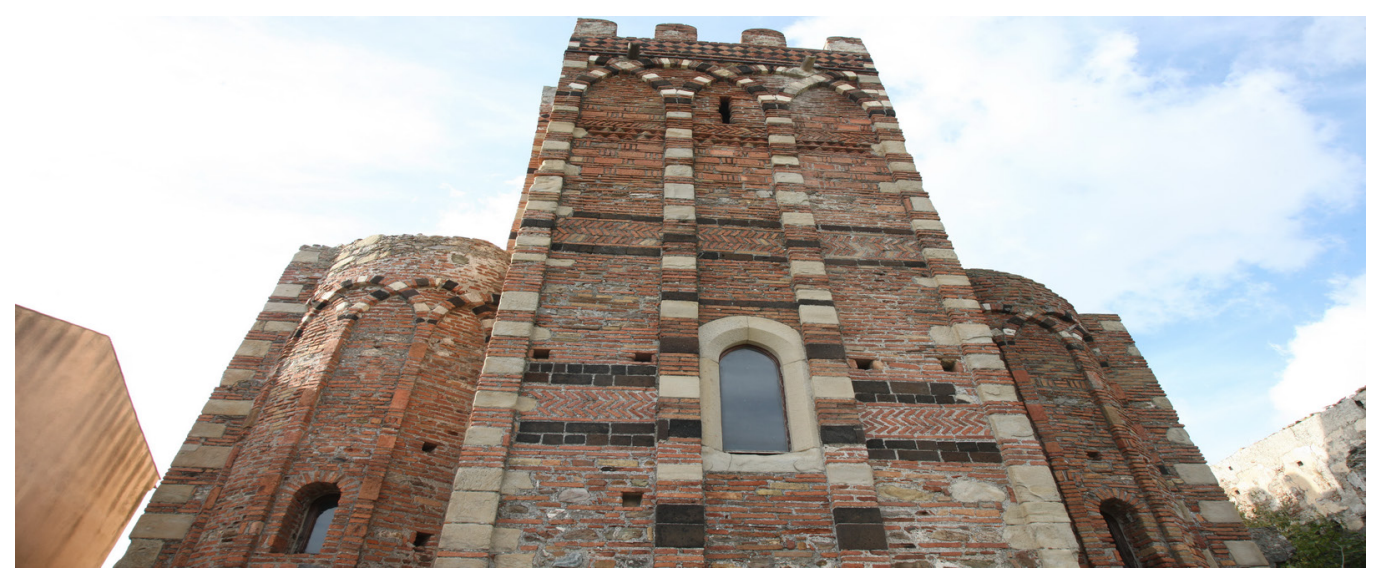




\section{Motivations and methodology}

This research concerns the study of a particular Basilian church of Saints Peter and Paul d'Agrò, located in the territory of Casalvecchio Siculo in the province of Messina, attributable to the period of the Norman reconquest. The choice to study this monument is due to several reasons:

- the building of worship is located in a wider context, marked by that moment of transition between the Greek and Latin traditions, between central and longitudinal systems, where architecture becomes a symbolic language of the mutual relationships between man, clergy, monarchy and divinity;

- the presence of Basilian plants due to remakes of those of the Greek rite, or to new interventions, attributable to the period of reconquest is a widespread phenomenon in the Demone valley: the church of San Pietro and Paolo d'Agro, represents the evolutionary moment of this phenomenon;

- the possibility to face the study through digital survey with 3D laser scanner and SFM, has allowed a greater precision and deepening by adding digital elaborations in $3 \mathrm{D}$, in order to draw precise analyzes;

- it belongs to that kind of monuments that could be observed for a long time, and each time it is possible to find new peculiarities.

In the period of the Archimandrite of Messina of the SS. Salvatore in phari language, a fervent building and reconstruction activity has a number greater than seventy Basilian monasteries in val Demone alone, mainly fortified and placed on the ridges of tortuous valleys conveniently hidden from the sea, affecting a wider territory of the current province of Messina [Basile 1975]. Just as the one in San Pietro e Paolo di Itala (ME), represents for some the first factory since the reconquest, the one in the Agrò valley is considered the later and more mature result of a reconstruction from a previous plant. The opportunity for analysis of one of the most studied Basilian churches, more interesting, but also more controversial on the lonian side of the island and the whole Demone valley, is proposed with advanced digital survey technologies, integrated with each other, and with a beware of $V R$.

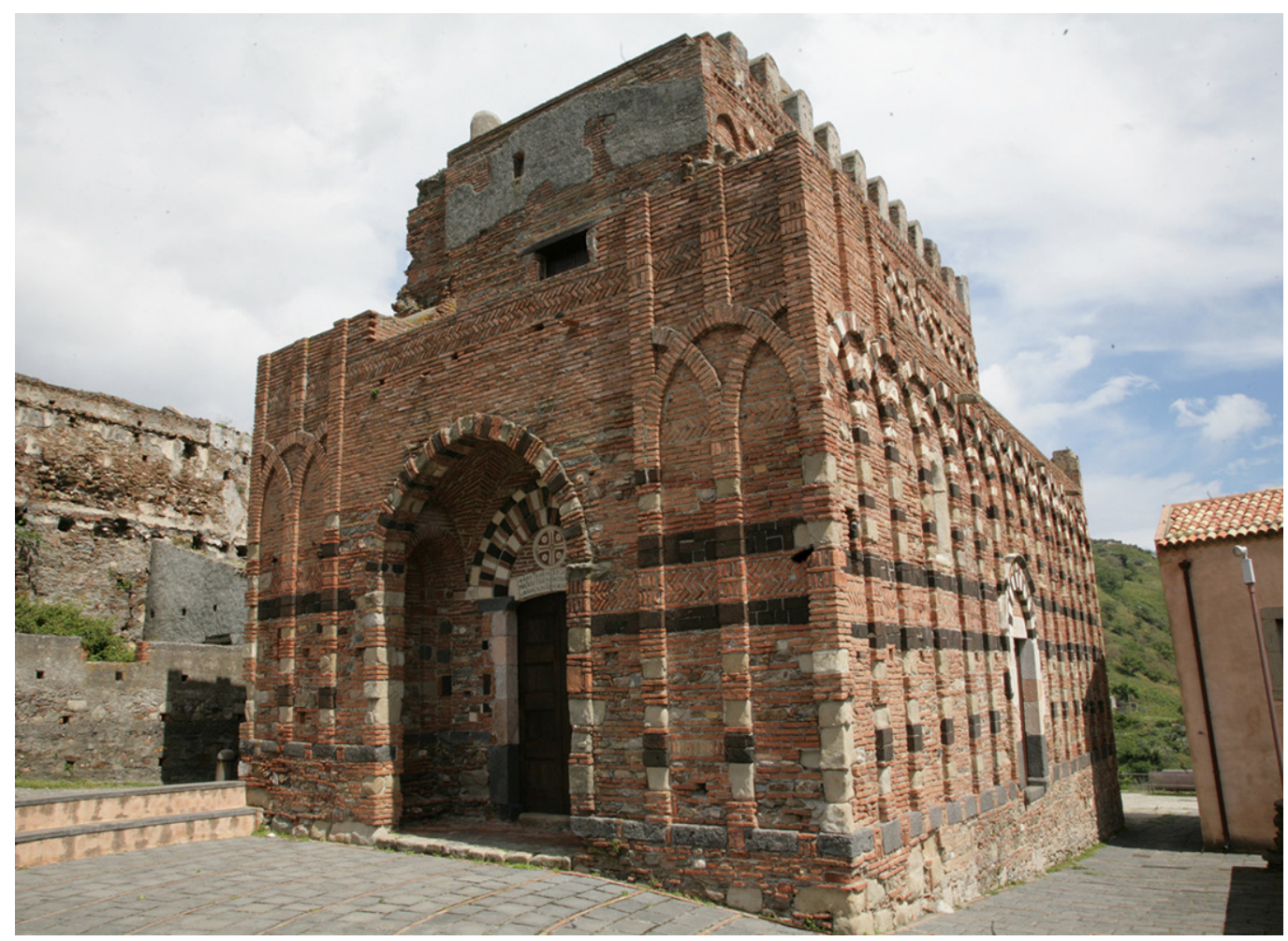




\section{The historical news}

We know that the early church presumably dated back to around 560, and that it was destroyed by the Arabs. It is not known what was recovered from the first implant. The reconstruction date of I I 7 comes from an 'Act of Donation' by Ruggero II, dated I I I 6 written in Greek [I], which shows that on a journey from Messina to Palermo he makes a stop in scali S. Alexii, where he is approached by the monk basiliano Gerasimo, who asked the sovereign for the faculty and resources to rebuild (erigendi et readificandi) the monastery located in the fluvio Agrilea. After accepting the request, the monk Gerasimo, who later became the first abbot of San Pietro e Paolo, immediately worked to erect the temple [Fazello 1817, pp. 137]. The reconstruction of Gerasimo is not the one we have received, the earthquake of I 169 produced considerable damage and while maintaining the same structure, today's church can be traced back to II72, as the Greek inscription on the portal bears: "was renewed this temple of SS. Apostles Peter and Paul from Teostericto Abate of Taormina, at his expense. May God remember him. In the year 6680. The protomagister Gherardo il Franco" [D'Amico 1979, p. 102] [2]. The clarification that the master builder was Norman concludes the architectural process, which began with the Byzantine style and followed by the Arab one. The most evident peculiarity of the factory lies in the architectural organization, in the synthesis between the centrality of the Greek and the Latin cross, between the tall and slender median nave extended to the apse tower, and the vertical axis of the dome. In some studies it is reported that Latin or commissa cross plants, with a monocentric dome on one or more spans, are to be found in the Byzantine area in Asia Minor and Armenia [Campo 1997, p. 97]. At the end of the schism of I054, from which the dichotomy of the two religious conceptions was now formalized, the common root of the faith seems to find the symbolic synthesis in the organization of this factory, in which it balances and contrasts the idea between a central plant, interpreter of redemption and contemplative spirituality, and a longitudinal symbol of expiation. Summary that should not be sought in the historical meaning or by design option, but only for political debt by the Basilian monks to the Altavillas, apostolic legates [3]. Without dwelling on the votive meaning addressed to Saints Peter and Paul to which many churches of the val Demone are dedicated, it should be remembered that the Norman reconquest for its war needs, relied on the only structure still existing in the area with its network of information: the monastic order. This was the only structu-

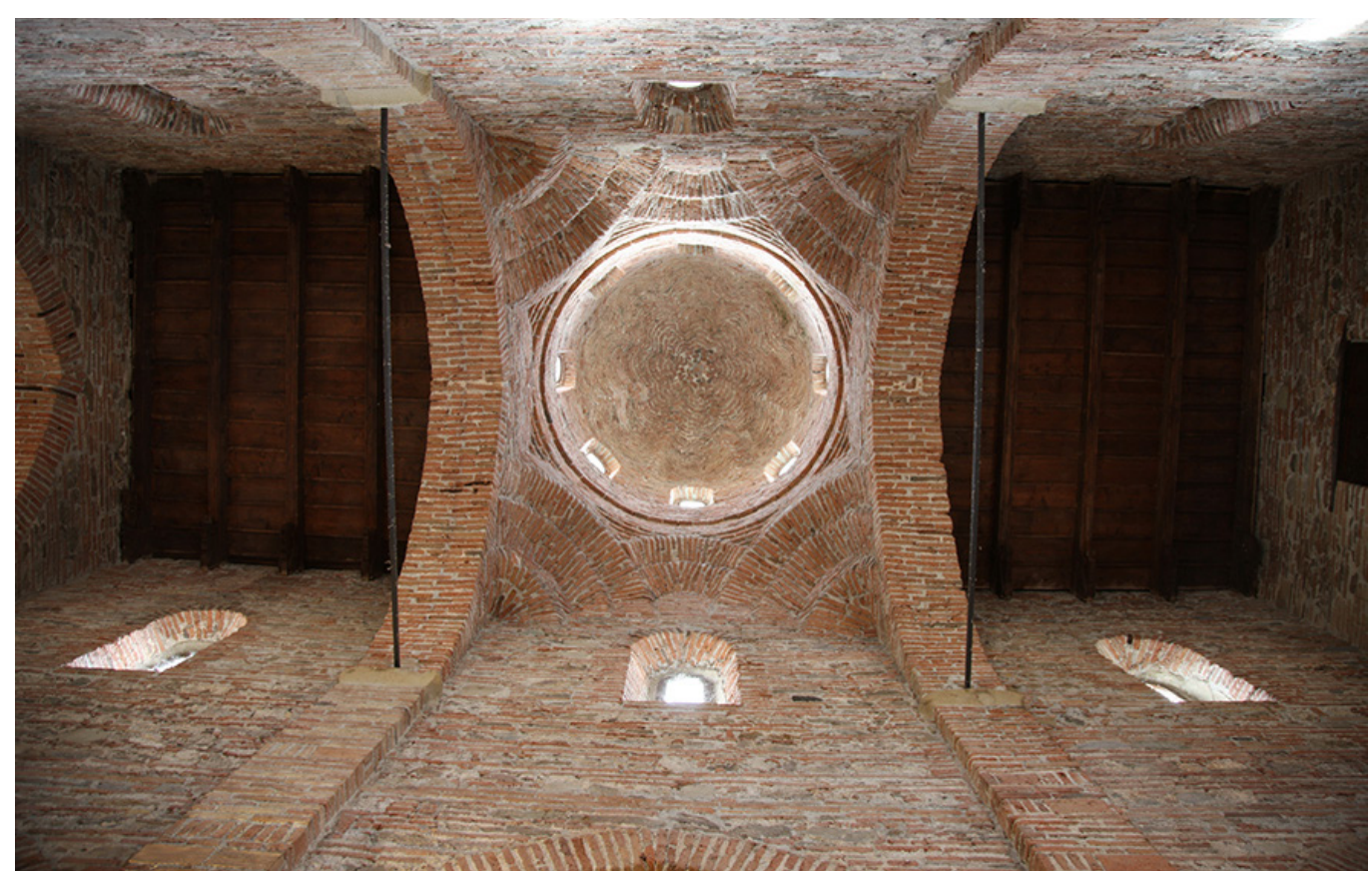


red organization in a territory where there was no longer any control and administrative structure after the Muslim invasion. Therefore, it is no wonder the request of the Basilian monks to the Altavila, in the figures of Roger I and Roger II, for the rebuilding of the places of worship in the Val Demone, this being the first part of the island to be freeded. Nor is it any wonder that in an area previously marked by the Greek Orthodox tradition, with examples of Greek cross implants, now it was decided to build and re-build Latin cross implants as a tribute to the Normans. The cross and the sword, whose sign overlaps and merges into the symbolic imagination, recaptured the territory at the same time.

\section{The architectural system}

The church in plan measures approximately $20.54 \times 11.24 \mathrm{~m}$, considerable dimensions referring to the Byzantine period [4]. If you draw a line coinciding with the axis of the central nave you will find that it forms an angle of 105 degrees with the north, a value that does not coincide with the east, but prolonging the line, it is found that it points towards the city of Jerusalem, an interesting orientation operation, considering the means and knowledge of the time. Access to the church is anticipated by an exonarthex inserted between two scalar towers, concluded at the intrados with a cross vault. We do not know if the two scalar towers, now absent, belonged to the first Byzantine structure, moreover they delimited the imperial chapel, an element that takes on meaning only with the advent of the Norman kingdom. Inside, the three naves end in as many apses accused on the outside: the two lateral ones with their curved geometry and the central one distorted by a parallelepiped. The set of these three elements is impenetrable, just from that side of the river that turns towards the lonian sea. The separation of the naves is marked by columns surmounted by pointed arches, while in the other direction the longitudinal one, the space is divided into three bays. This choice is combined with the idea of placing the main dome in a central position, an operation not feasible in other situations with an even order of spans, such as the nearby Basilian church of San Pietro and Paolo di Itala (ME), organized in four arches. The higher central nave is characterized by two domes of which the larger one concludes the central span at the top, the other smaller one anticipates the central apse, while in the

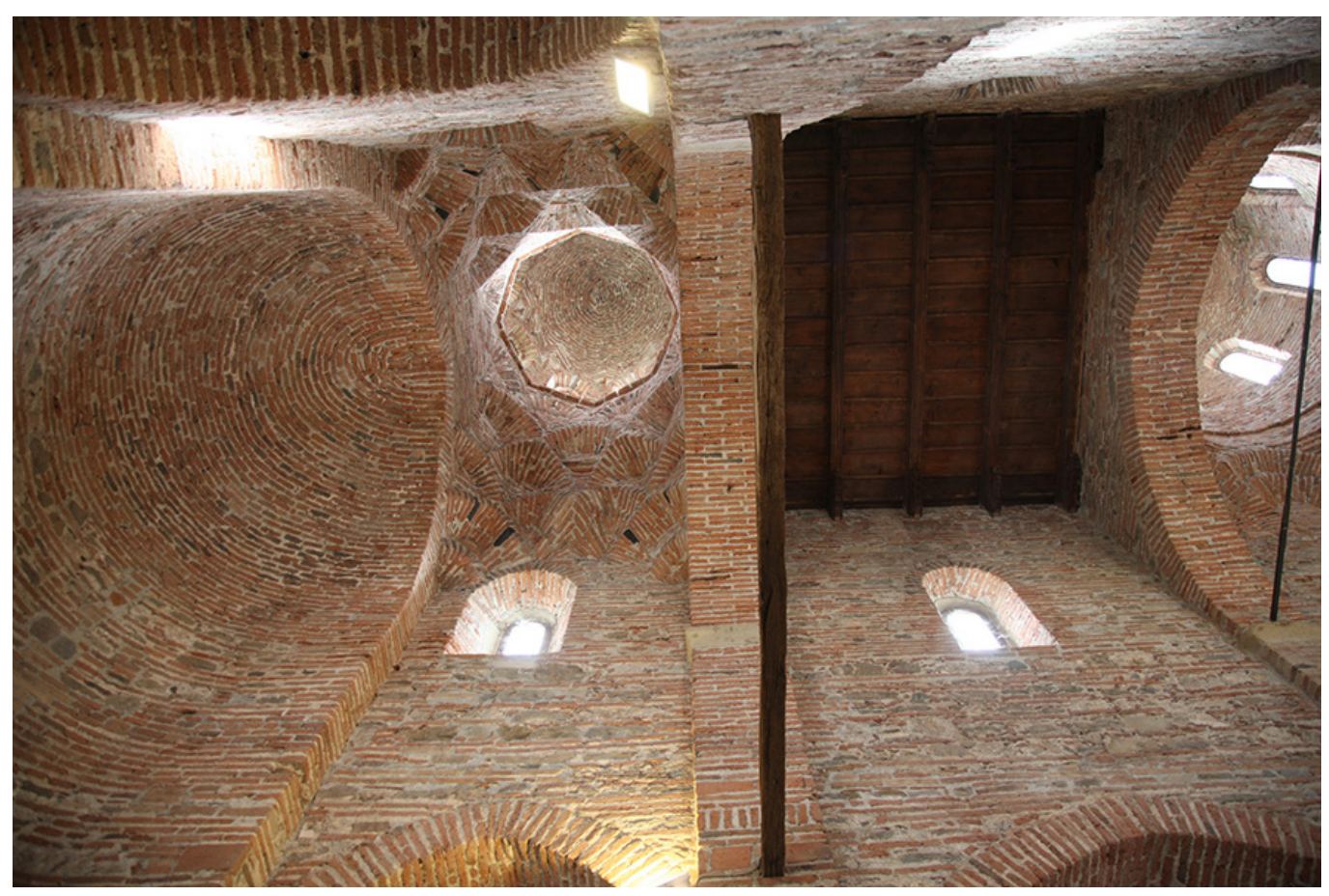


Fig. 4. The station on the west side with the 3D laser HDS 3000

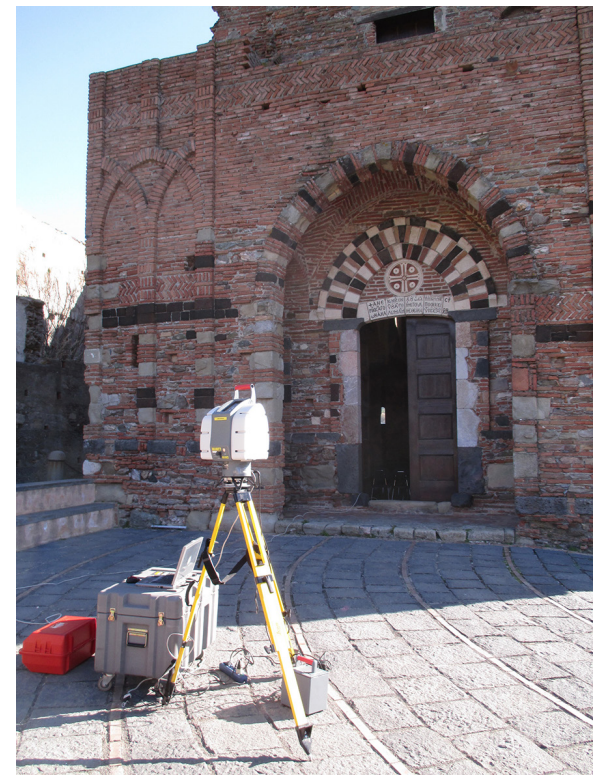

remaining two spans the roof is flat. To find another three-span longitudinal system of the same period, Norman and Basilian, one must move to Calabria in the church of Santa Maria de'Tridetti, where however the only dome appeared to be on the transept. The centrality of the dome in western religious models does not seem to find previous evidence on the vertical centerline of the longitudinal axis. This particularity has been seen from many sides as the synthesis between the centrality of the Greek and the Latin cross, between the tall and slender middle nave extended to the apse tower, and the vertical axis of the dome. Narrower and lower are the side aisles surmounted by crossbars on the intrados, set on a rectangular plan. But the concession to the Altavillas is not limited only to the Latin cross plan, their power sanctioned with the apostolic legacy is manifested in many churches on the island: the position of the king is higher not only than that of the clergy, but also that of the priests, this representativeness of the role is testified by the surviving still visible window of the imperialis chapel, which no longer exists today. Originally constituted by a western body, positioned above the exonarthex, defined westwerk in the tradition of the regions beyond the Alps, it is certainly to be attributed to the wealth of knowledge of the protomagister Girado il Franco, and moreover it combines with the advent of the monarchy. On the extrados the coverage of the entire system is flat with the exception of the two domes, of which the central one unloads the weight on four columns that delimit the rectangle on which the spherical geometry is set, the passage from the circle to the rectangle is mediated with six orders of plumes. Eight windows along the drum allow lighting and mark the eight segments of the cap. The two side doors along the aisles, report different differences, the most obvious being their staggering. The southern one, placed in a median position, is the most ambitious, repeating over the arc part of the polychrome motifs of the entrance portal, but its significant difference in altitude with the countryside plan raises questions about its function. The other door, the one along the northern side, located in the last arch, reports a coarse insertion on the outside both along the piers and above the architrave, also leaving a trace of a previous arch visible from the inside. On the outside, the slope of the country floor is leveled by a base marked by a strip and staggered near the narthex. On all external sides, the decoration is done by means of just projecting pilasters which end at the top with a series of intertwined arches and which divide the circumference module in half, the same motif is taken up along the elevated elevations of the central nave. The dominant material and therefore the color, is that of brick, other materials refer to the local quarries: the lava pumice, the yellow sandstone, the limestone. 
Fig. 5. The plan and the

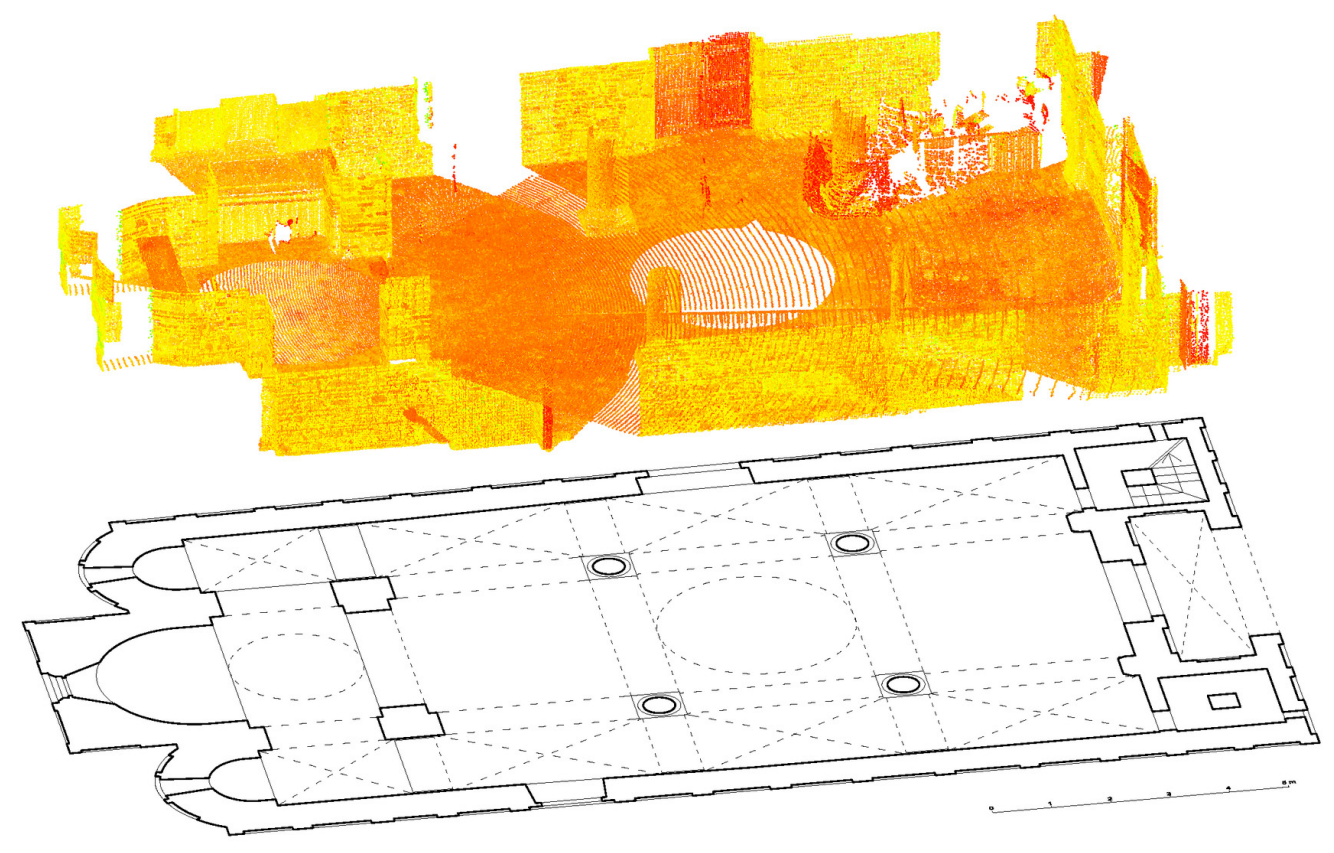

Fig. 6. Vertical section of

the cloud, and graphic
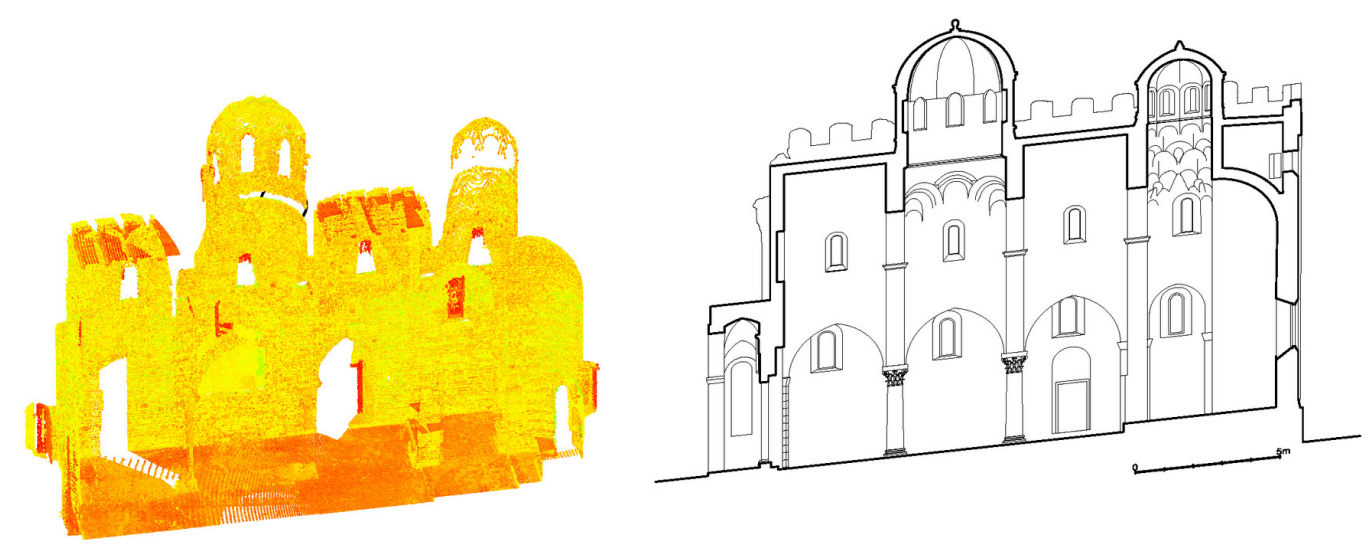


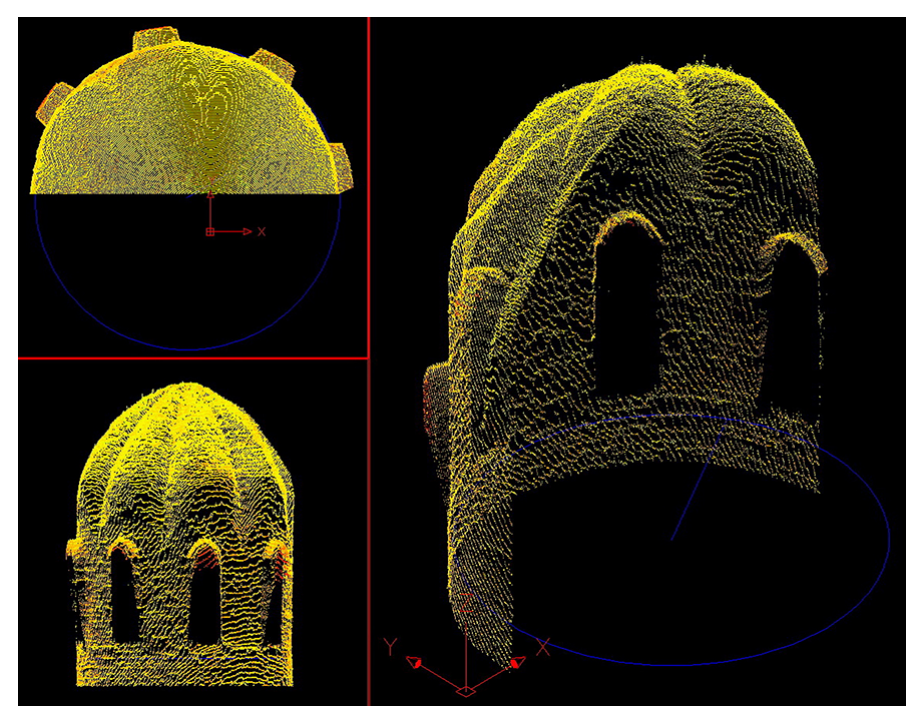

\section{The survey}

The study was dealt with in a mixed way: by 3D laser scanner, SFM methodology and dense matching, some parts by direct survey with Leica Disto-D8 distance meter with inclination sensor. The 3D laser scanner used is a Leica HDS 3000, in flight time, with which two internal and three external stations have been performed in order to eliminate the shaded areas. The two internal stations were carried out with the instrument in a zenithal position under each of the domes, in order to resume the entire geometry. The definition of the points was set with a I $\times I \mathrm{~cm}$ square mesh grid at an average distance of $7.00 \mathrm{~m}$. The first of the three external stations was located in front of the main entrance, the second near the south-west cantonal, the third in the middle of the western side aligned with the door.The definition of the external clouds was set with a $|x| \mathrm{cm}$ grid at an average distance of approximately $8.00 \mathrm{~m}$. As a priority, the two internal scans have been merged, then the three external ones separately. In addition, the two external scans aligned near the portals have also detected internal parts, in this way it was possible to combine all the internal scans with the external ones. For the union of the clouds, a maximum residual error of $4 \mathrm{~mm}$ was accepted, thus obtaining a single numerical model. SFM projects were developed separately using the Zephyr programs of 3DFlow, and Metashape of Agisoft, which involved: the entirety of the external part, the internal volume of the exonarthex, the prospect relative to the main entrance, the outside of the apsidal part and the interior of the church. A full frame Canon EOS-I Ds Mark III camera was used, the advantage of which is to have a wider angle of view in tight spaces. During the photographic acquisition phase, particular attention was paid to acceptable sharpness over the entire frame, combining aperture and shutter speed, also taking into account that the optics used are stabilized. During the processing phase, a selective check was carried out, discarding those photos that moved or blurred lost sharpness even in some parts. The difficulty of these programs in performing the union in the presence of uncertainties for the pixels caused by the wake effect is known and has been discussed in several articles. Then the average Ground Sampling Distance (GSD) was calculated, for a sample of photos of the outside. For the internal parts, taking into account the parameters of the photographic sensor equal to $35.8 \times 23.9 \mathrm{~mm}$, the GSD was equal to $2.4 \mathrm{~mm} /$ pixel, which for average distances from the object of about $8 \mathrm{~m}$ means a covering real image of $10.88 \mathrm{~m}$ wide and $7.05 \mathrm{~m}$ high. These values were considered valid for the purposes of the survey, as they ensured a good definition of the detail compatible with the quality of the survey performed with the 3D laser scanner. 
Fig. 8. The plan: modulation in Greek poles and

Sicilian pipes, geometric matrices.

Fig. 9. The sections: modulations and proportions of the parts in elevation.
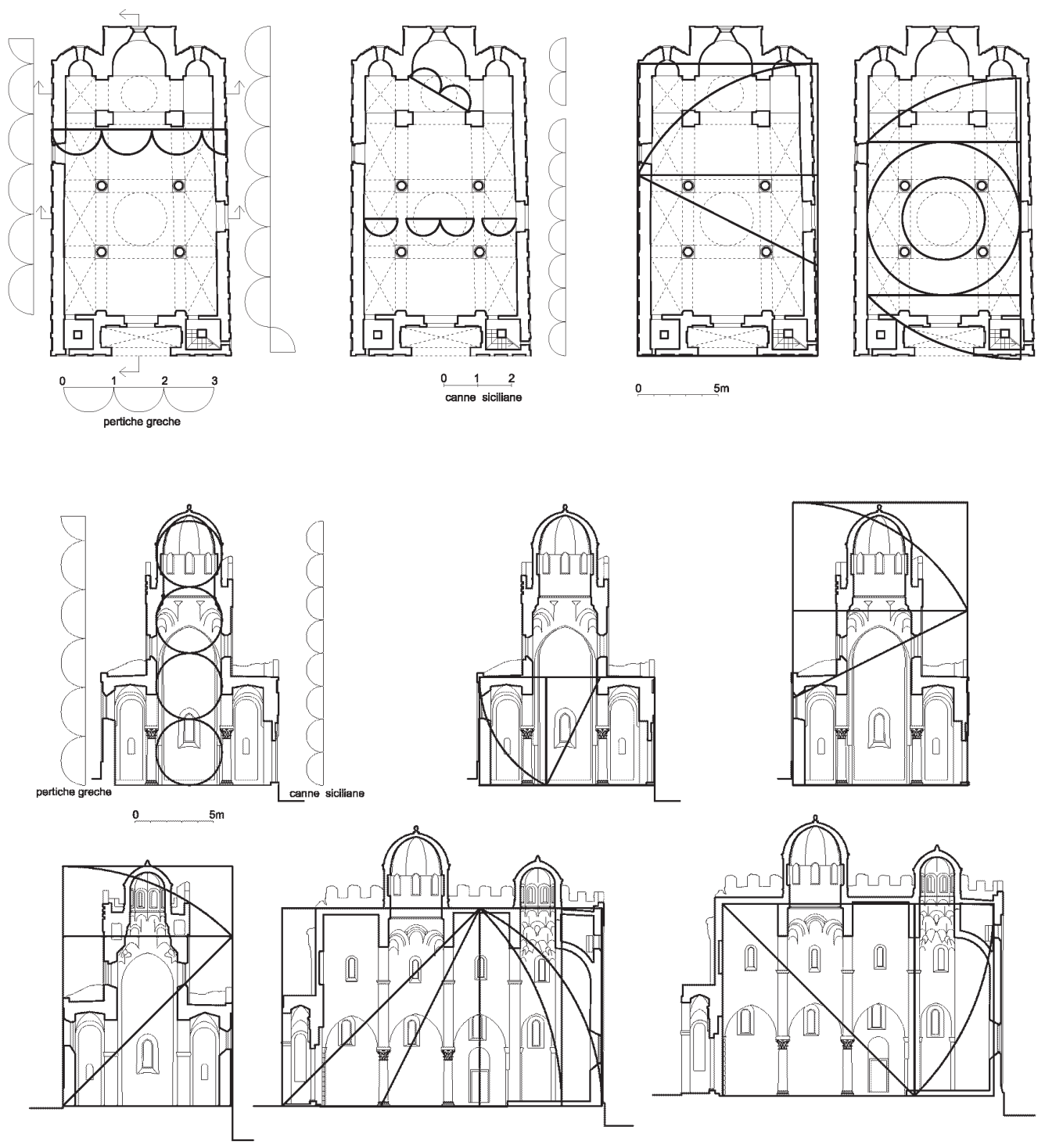

Fig. 10. SFM model elaboration with Zephyr 3D Flow, 3D view west and south sides.

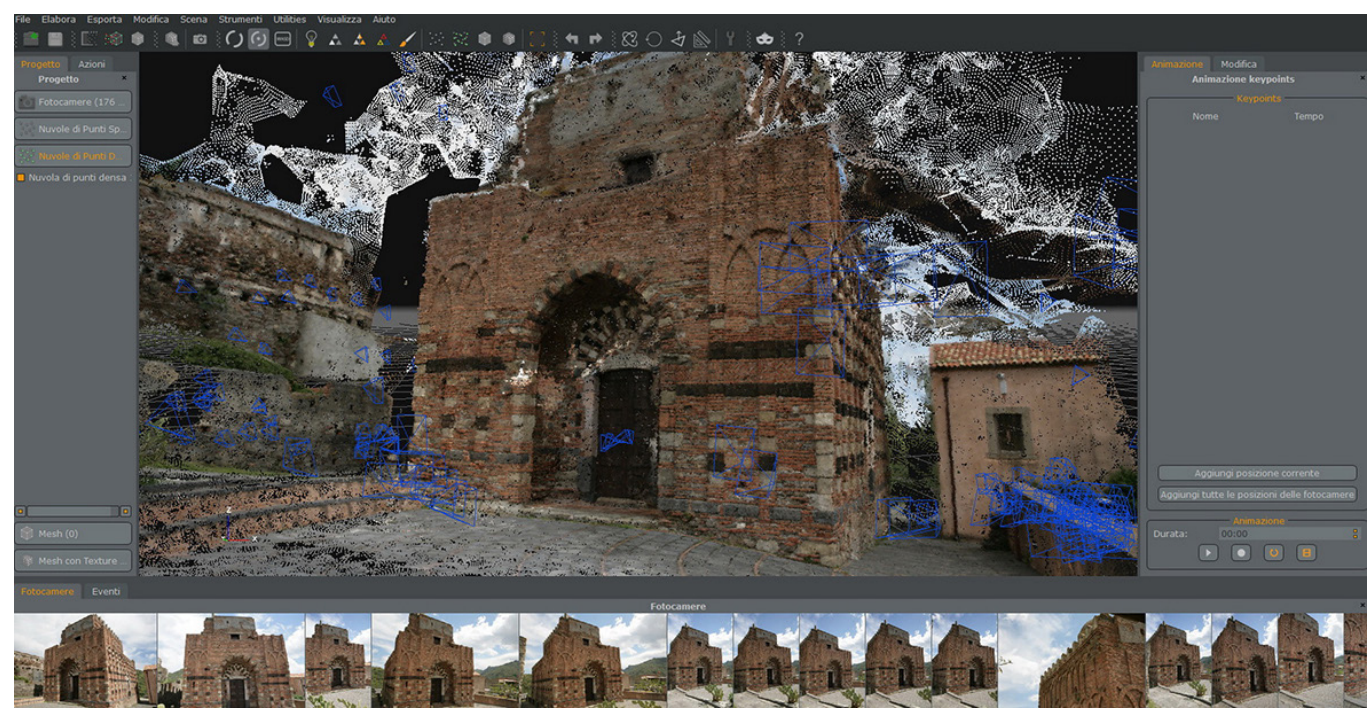


Fig. II. SFM processing (n) south sides.
During the SFM processing phase, a compromise was sought between some significant parameters and the processing times, such as the density of the Keypoints and the depth of the matching phase. Then the dense cloud with mesh and texture was elaborated, in order to appreciate the quality near the elevations of the long sides, thus obtaining the geometric model. Some critical points were found in the vicinity of the pilaster strips. Subsequently, the numerical model of the west and south elevations of the laser cloud was developed, combining it with the east and north elevations of the SFM cloud, obtaining a single scaled numerical model. The graphic restitution phase of the plant was performed using the point cloud starting from the Cloudworx application. Overabundant control measurements were performed with the Leica Disto-D8 laser distance meter, to verify some critical issues such as the convergence of the long sides in the direction of the apses.

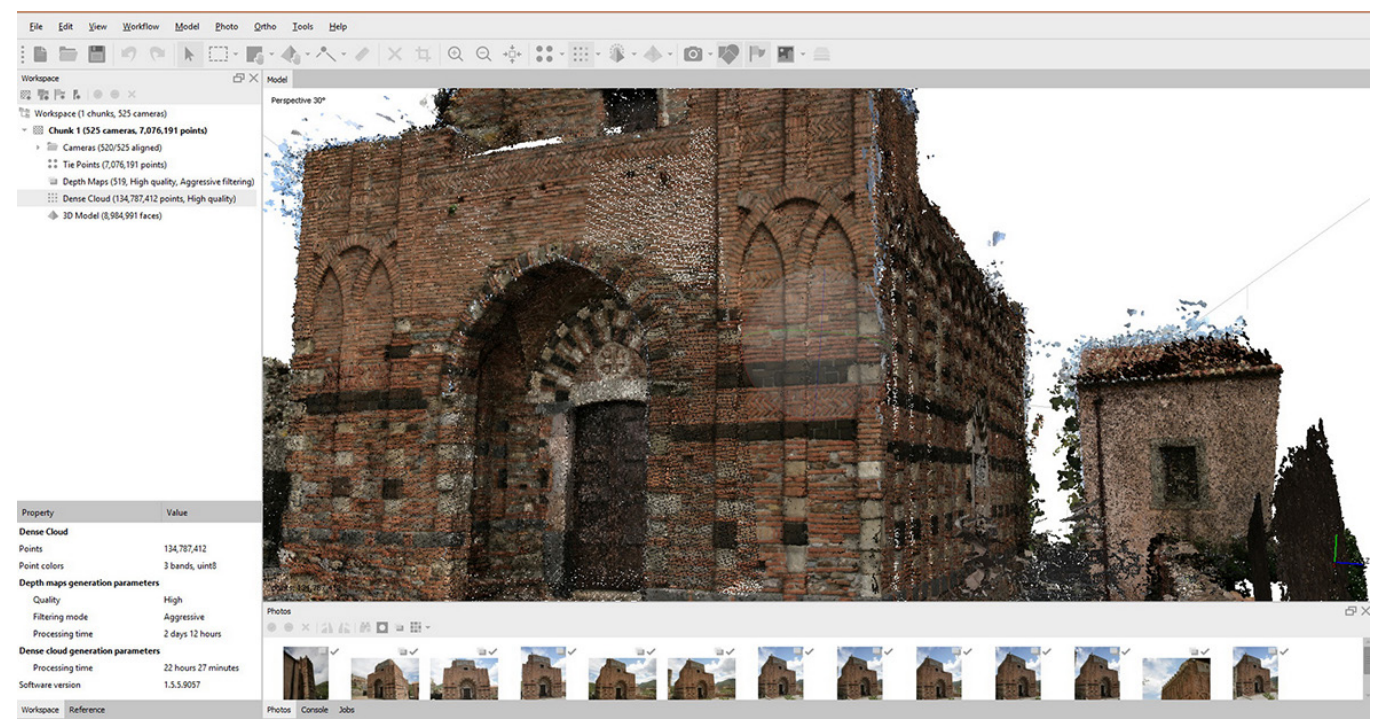

The achieved results

As already mentioned, we do not know how much of the church that has come down to us belongs to the primitive plant. Of the most emblematic features that testify to the Byzantine style, today we still have the division of the three naves into three centric modules, the polychrome of the various members, the capitals, the Greek cross above the architrave of the entrance door. Of the Arab one, the two domes with the terminal part and the theory of members supporting the domes. The Norman imprint is evident in the entrance marked by the towers, a recurring symbol in the Norman cathedrals made in Sicily. From the graphic analysis, results were obtained regarding the sizing and proportions. The modulation of the plan and the elevated parts starting from the sections was sought. The modulus used is the Greek foot [5] equal to $0.312 \mathrm{~m}$, whose multiple is the perch equal to 10 feet.This measure is repeated in plan in the two directions, which are $5.5 \times 3$ poles for the internal part, net of the walls and the exonarthex, and $6.5 \times 3.5$ poles at the maximum dimensions of the walls (figs. 8, 9). In elevation, near the main dome, 5.5 poles were counted, with intermediate values that mark the significant parts. The 5.5 poles equal to about $17.16 \mathrm{~m}$ in both directions, both in elevation along the main dome and in the direction of the central nave, demonstrate in their juxtaposition the symbolic meaning of mediation between the two liturgical traditions. The value of $3.12 \mathrm{~m}$ is equal to the diameter of the circumference measured on the tax plane of the largest dome and coincides with 10 feet. It could be concluded that the whole plant was sized on the circumference of the dome, organized on the Greek form. 
A modulation was also sought with the ancient unit of measurement of Sicilian rods [6], but the result obtained satisfies only some parts. With regard to the geometric matrices, it has been found that the rectangle that defines the plan is defined by the golden ratio of the square having the side equal to the width of the building. A modulation was also sought with the ancient unit of measurement of Sicilian rods [6], but the result obtained satisfies only some parts. With regard to the geometric matrices, it has been found that the rectangle that defines the plan is defined by the golden ratio of the square having the side equal to the width of the building. Then another proportion was sought starting from the square of the central core defined by the circumference with the center in the projection of the dome and tangent to the internal sides of the plan, using the reversal of the diagonal (fig. 8). Relations between the parts were also found in elevation: the height of the main dome is defined by a golden ratio with the width of the building, the smaller dome is defined by the overturning of the diagonal of the square with a side equal to the width of the building. Relationships based on the golden proportion and on the diagonal overturning have been found in the longitudinal section of the central nave (fig. 9).

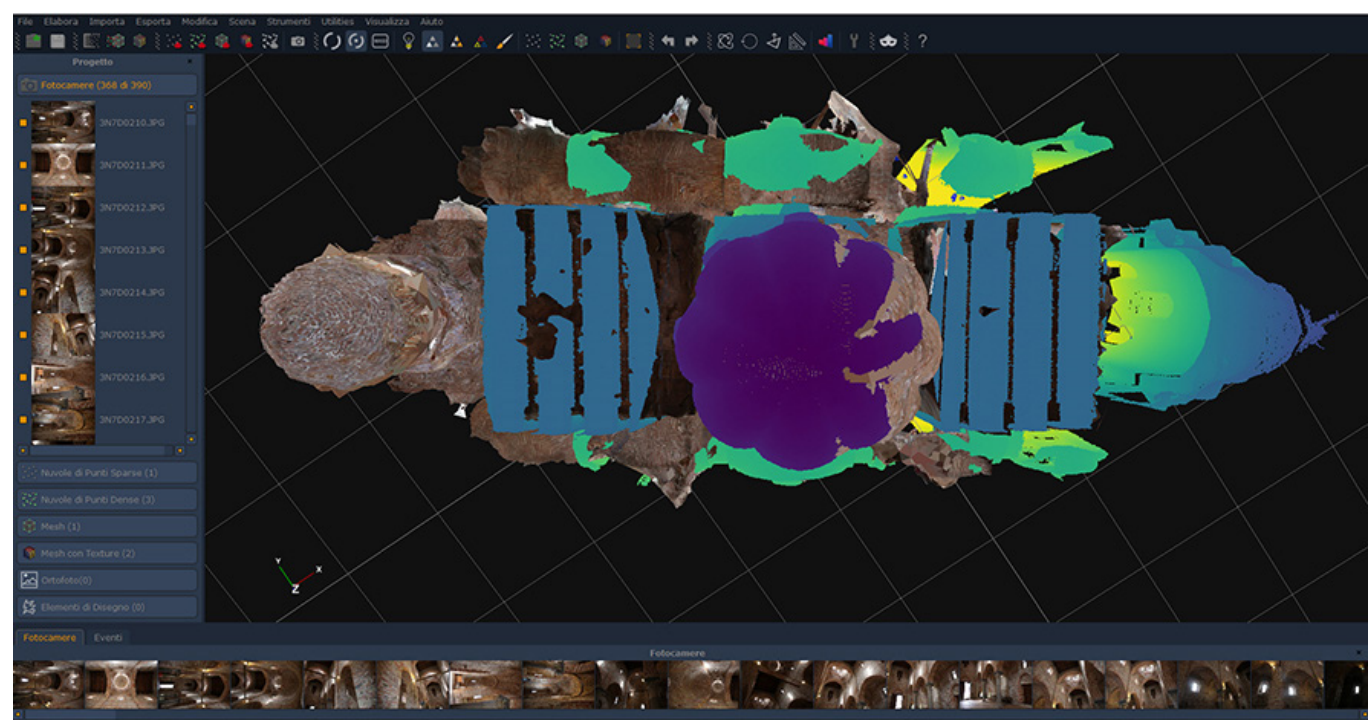

\section{Conclusion}

Modulations, proportions, signs, drawings, interpretations of the cross in that reference to that Latin and Greek vision, indispensable for finding the key to reading those invariable examples of all the things that have been. In this temple of worship the apical place of dialogues and relationships between different civilizations and cultures shines through, in the eternal search for the overcoming of conflicts and divisions. A cult building on the mouth of a river that reaches a 'narrow' sea between two lands, but still narrower between many civilizations.

\section{Notes}

[I] Preserved in the Vatican Code 820 I, translated into Latin by Costantino Lascaris in 1478.

[2] The year 6680 corresponds in the Greek-Byzantine chronology to 1 172. The inscription on the portal is in Greek, the translation on several volumes was in: D'Amico Mario (1979). Palachorion. Catania-Verona: Niccolò Giannotta Editore, p. 102.

[3] The king was given the power to invest the priests, and to judge religious matters [Campo 1997, p. 96].

[4] For the size of the buildings of worship in Byzantine Sicily, see: Buscemi, Tomasello, 2008, pp. I31, I 32 
[5] Although it differs slightly from the Roman one of $0.2956 \mathrm{~m}$. The observation demonstrating how the factory and the territory were permeated by the Byzantine culture rather than the Roman tradition is interesting. The measure equal to the Greek foot varies between $0.308 \mathrm{~m}$ and $0.315 \mathrm{~m}$ [Buscemi, Tomasello, 2008, pp. I I0- I I I]

[6] In the Norman period, the 8-palm barrel with a value of 2. 109360 meters was used, which will be legalized with corrections by the edict of April 6, I480, issued by Ferdinand I of Aragon.

\section{References}

Arena Marinella, Colistra Daniele, Mediati Domenico (2019). Architettura bizantina in Tessaglia. Le chiese del Monte Kissavos. In Stefano Bertoccci, Antonio Conte (a cura di). II Simposio UID di internazionalizzazione della ricerca. Patrimoni culturali, Architettura, Paesaggio e Design tra ricerca e sperimentazione didattica. Atti del Symposium of Representation Scientific Area for the development of multidisciplinary International programs. Matera, 22 ottobre 2019 . Firenze: diapress, pp. 74-79.

Basile Francesco (1938). Chiese siciliane del periodo normanno, I monumenti italiani, fasc. XV. Roma: Accademia d'Italia.

Basile Francesco (1975). L'architettura Della Sicilia Normanna. Catania-Caltanissetta:Vito Cavallotto Editore.

Bottari Stefano (1927). Nota sul Tempio normanno dei SS. Pietro e Paolo d'Agrò. Messina:Tipografia ditta D'Amico.

Bottari Stefano (1939). Chiese basiliane della Sicilia e della Calabria. Messina: Officine grafiche Principato.

Buscemi Francesca, Tomasello Francesco (2008). II paesaggio Tardoantico del territorio. In Buscemi Francesca, Tomasello Francesco (a cura di). Una testimonianza di cristianizzazione orientata. Palermo: Alberto Musco, pp. I3I, I32. <www. progettokasa.net>.

Calandra Enrico (1938). Breve storia dell'architettura in Sicilia. BaRi: Laterza. Ristampa (1996) Torino:Testo \& Immagine.

Campo G. ( 1 997). Casalvecchio Siculo, Monastero dei SS. Pietro e Paolo d'Agrò. In I Quaderni dell'Abbazia, 2, I 997.

D’Amico Mario (1979). Palachorion. Verona: Edizioni Giannotta.

Fazello Tommaso (I8I7). Della Storia di Sicilia - Deche Due. Vol. I. Palermo: Tipografia Giuseppe Assenzio. (Traduzione in lingua toscana). Archiviato il 29 novembre 2015 in Internet Archive: <https://archive.org/details/bub_gb_hM2XPuLTSDgC/ mode/2up>.

Freshfield Edwin Hanson (1918). Cellae trichorae and other christian antiquities in the byzantine provinces of Sicily with Calabria and North Africa including Sardinia, vol.2, p. 894. London: Rigon \& Arnold. Ristampa (20 I0) Londra: La Vergne: General.

Mamì Antonella (2008). Le chiese basiliane della Sicilia orientale. In Costruire in laterizio, $n^{\circ}$ I23, maggio-giugno.

Noto Vittorio (20 I2). Architetture medievali normanne e siculo normanne. Palermo: Pietro Vittorietti Edizioni.

Pirro Rocco (1733). Sicilia Sacra. 2 voll. Palermo: edizione Panormi. (Ristampa anastatica, Editore Forni, collana Italia sacra dicembre 1987)

\section{Author}

Giuseppe Di Gregorio, Università degli Studi di Catania, giuseppe.digregorio@unict.it

To cite this chapter. Di Gregorio Giuseppe (2020). San Pietro e Paolo d'Agrò, dalle origini al digitale/San Pietro e Paolo d'Agrò, from origins to digital. In Arena A., Arena M., Brandolino R.G., Colistra D., Ginex G., Mediati D., Nucifora S., Raffa P. (a cura di). Connettere. Un disegno per annodare e tessere. Atti del $42^{\circ}$ Convegno Internazionale dei Docenti delle Discipline della Rappresentazione/Connecting. Drawing for weaving relationships. Proceedings of the 42th International Conference of Representation Disciplines Teachers. Milano: FrancoAngeli, pp. 3247-3268. 